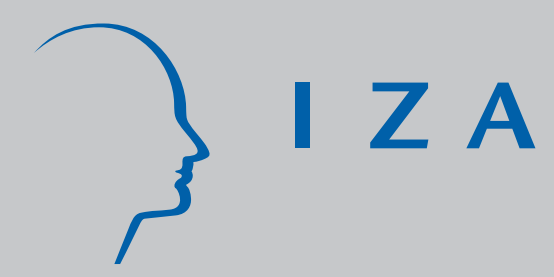

IZA DP No. 2280

Unemployment Insurance in Europe:

Unemployment Duration and

Subsequent Employment Stability

Konstantinos Tatsiramos

August 2006 


\title{
Unemployment Insurance in Europe: Unemployment Duration and Subsequent Employment Stability
}

\author{
Konstantinos Tatsiramos
}

IZA Bonn

Discussion Paper No. 2280

August 2006

IZA

P.O. Box 7240

53072 Bonn

Germany

Phone: +49-228-3894-0

Fax: +49-228-3894-180

Email: iza@iza.org

Any opinions expressed here are those of the author(s) and not those of the institute. Research disseminated by IZA may include views on policy, but the institute itself takes no institutional policy positions.

The Institute for the Study of Labor (IZA) in Bonn is a local and virtual international research center and a place of communication between science, politics and business. IZA is an independent nonprofit company supported by Deutsche Post World Net. The center is associated with the University of Bonn and offers a stimulating research environment through its research networks, research support, and visitors and doctoral programs. IZA engages in (i) original and internationally competitive research in all fields of labor economics, (ii) development of policy concepts, and (iii) dissemination of research results and concepts to the interested public.

IZA Discussion Papers often represent preliminary work and are circulated to encourage discussion. Citation of such a paper should account for its provisional character. A revised version may be available directly from the author. 


\section{ABSTRACT \\ Unemployment Insurance in Europe: Unemployment Duration and Subsequent Employment Stability ${ }^{*}$}

The empirical literature on unemployment insurance has focused on its direct effect on unemployment duration, while the potential indirect effect on employment stability through a more efficient matching process, as the unemployed can search for a longer period, has attracted much less attention. In the European context this is surprising as reform proposals of the unemployment insurance system aiming at reducing high European unemployment rates should consider both effects. This paper provides evidence on the effect of unemployment benefits on unemployment and employment duration in Europe, using individual data from the European Community Household Panel for eight countries. Country specific estimates based on a multivariate discrete proportional hazard model, controlling for observed and unobserved individual heterogeneity, suggest that even if receiving benefits has a direct negative effect increasing the duration of unemployment spells, there is also a positive indirect effect of benefits on subsequent employment duration. This indirect effect is pronounced in countries with relatively generous benefit systems, and for recipients who have remained unemployed for at least six months. In terms of the magnitude of the effect, recipients remain employed on average two to four months longer than non-recipients. This represents a ten to twenty per cent increase relative to the average employment duration, compensating for the additional time spent in unemployment. These findings are in line with theories suggesting a matching effect of unemployment insurance.

JEL Classification: J64, J65, C41

Keywords: unemployment insurance, unemployment duration, employment stability

Corresponding author:

Konstantinos Tatsiramos

IZA

P.O. Box 7240

D-53072 Bonn

Germany

E-mail: tatsiramos@iza.org

\footnotetext{
* I wish to thank Armin Falk, Andrea Ichino, Karl Schlag, and Jan van Ours for valuable suggestions and comments. This paper has also benefited from comments and discussions with Manuel Arellano, Christian Belzil, Samuel Bentolila, Pierre Cahuc, Muriel Dejemeppe, Dimitris Georgarakos, Dan Hamermesh, David Jaeger, Pierre-Carl Michaud, Ludovic Renou, Uwe Sunde, Prodromos Vlamis, and participants at the ESPE, EUI-Florence, Tilburg, and IZA. Any remaining errors are only mine. Financial support from the EUI and the CentER at Tilburg, as a Marie Curie Training Site under contract HPRN-CT-2000-00134, is gratefully acknowledged. This is a substantially revised version of IZA DP No 1163 entitled "The Effect of Unemployment Insurance on Unemployment Duration and Subsequent Employment Stability".
} 


\section{Introduction}

The disincentive effect of the unemployment insurance (UI) system has been the conventional wisdom in modern labor economics. ${ }^{2}$ Policy recommendations aimed at removing this disincentive effect often suggest reducing the generosity of the UI system. However, such reform proposals may have adverse policy outcomes as they focus on the direct effect of UI on unemployment duration without taking into account the potential indirect effects associated with improved employment stability. UI benefits provide the time to unemployed to search for a job that matches their ability, rather than being forced by financial hardship into accepting the first available job offer (OECD, Employment Outlook, 1996, p.28). Theoretically, this positive effect of UI can be explained by standard search theory where UI benefits can be interpreted as a search subsidy (Burdett, 1979), increasing reservation wages and subsequent quality of job matching. In the macro-labor literature, Marimon and Zilibotti (1999), in an equilibrium search-matching model, show that UI has the standard effect of reducing employment, but also helps workers to get jobs which are compatible with their skills and therefore less likely to dissolve.

Considering these positive features of UI is relevant to policy as the European challenge to achieve full employment is a long-term target, which requires not just to attract more individuals to the labour market, but also to ensure employment stability. Surprisingly enough, there is no empirical evidence at the European level to reconcile the two effects. ${ }^{3} 4$

This paper contributes to the empirical literature by investigating the effect of UI on

\footnotetext{
${ }^{2}$ Atkinson and Micklewright (1991), Devine and Kiefer (1991) provide comprehensive reviews of the theoretical and empirical literature on the effect of the unemployment benefit replacement rate. Empirical studies investigating the link between the potential benefit duration and the duration of unemployment include Katz and Meyer (1990); Card and Levine (2000) for the US, Lalive and Zweimüller (2004) for Austria.

${ }^{3}$ Ehrenberg and Oaxaca (1976) are the first to consider the effect of UI on post-unemployment outcomes focusing on re-employment wages, while Belzil (2001) investigates the effect of UI on both unemployment and re-employment duration in Canada. Baker and Rea (1998) for Canada, and Jurajda (2002) for the US, look at the effect of future entitlement of UI on employment duration. Recently, Van Ours and Vodopivec (2006) investigated the effect of the UI system reform in Slovenia on both unemployment and postunemployment outcomes. Section 2 contains a detailed discussion of these studies.

${ }^{4}$ In the policy evaluation literature there are studies on the effect of training on unemployment and subsequent employment duration using individual transition data, e.g. Gritz (1993), Ham and LaLonde
} 
both unemployment and subsequent employment duration in Europe employing individual data from the European Community Household Panel (ECHP, 1994-2001) for eight European countries (Denmark, France, Germany, Greece, Italy, Ireland, Spain, and the UK). ${ }^{6}$ The ECHP is a survey based on a standardized questionnaire with annual interviewing of a representative panel of households and individuals in each EU country. Similarly to Bover, Arellano, and Bentolila (2002), the effect of UI is identified by a comparison between recipients' and non-recipients' outcomes. Contrary to many other studies which identify the effect of UI benefits by using variation on the level and the potential duration of benefits, the ECHP provides limited information on these main characteristics of the UI system. Instead, a time-varying indicator of benefit receipt is constructed. The econometric analysis adopts a reduced-form approach by estimating separately for each country multivariate discrete proportional hazard models addressing two important issues: (a) the endogeneity of the benefit indicator variable, and (b) the endogeneity of previous unemployment duration on subsequent employment duration. Any such correlation may be spurious if unobserved characteristics, such as ability or motivation, are associated with the length of unemployment and employment spells. To disentangle the true effect of previous unemployment duration from spurious correlation, unobserved heterogeneity is allowed to be correlated between unemployment and employment spells.

The empirical results suggest that receiving unemployment benefits reduces significantly the hazard rate for leaving unemployment, which leads to longer unemployment duration. This confirms both the theoretical predictions and the extensive empirical literature on the effect of benefits on unemployment duration. Moreover, the effect of receiving benefits on unemployment duration is larger in countries with more generous UI system, such as France and Germany.

The important contribution of the paper is that despite this direct negative effect of UI, which translates into longer unemployment duration, there is a positive indirect effect

(1996), Bonnal et.al. (1997), Van Ours (2001).

${ }^{5}$ For a brief description of the UI system in each of these countries see appendix A.

6 The paper focuses on employment duration, which includes job to job transitions, as a measure of employment stability. Therefore it investigates the probability of re-entering unemployment. The ECHP does not contain information on whether the worker is working with the same employer or not, which could be used to identify job to job transitions. 
of UI on subsequent employment stability. ${ }^{7}$ It turns out that the hazard rate of exit from employment is lower for benefit recipients during their previous unemployment spell compared to non-recipients. This indirect effect is pronounced (a) in countries with relatively more generous benefit systems, such as Denmark, Germany, and France, compared to countries such as Greece and Italy where the UI system is underdeveloped, and (b) for recipients who have spent at least 6 months in unemployment. In terms of the magnitude of the effect, recipients remain employed on average 2-4 months longer, which represents a 10-20 per cent increase relative to the average employment duration. This offsets the direct effect of UI benefits suggesting a non-negative net effect.

These findings are in line with theories suggesting a matching effect of UI which seems to be relevant in countries with a relatively more generous UI system. From the policy perspective, these results indicate that reform proposals of the UI system should take into account both the direct and the indirect effects for designing an efficient system in order to achieve the goal of higher employment in Europe.

The rest of the paper is organized as follows. Section 2 outlines the theoretical framework and the existing empirical evidence, while Section 3 describes the data employed for this study. The econometric model is presented in Section 4, and the results of the empirical analysis in Section 5. The conclusions of the study are drawn in the last section.

\section{Theoretical Arguments and Empirical Evidence}

The theoretical analysis of the potential effect of UI benefits on the escape rate out of unemployment is based on models of job search (e.g. Mortensen, 1977; Devine and Kiefer, 1991; Lippman and McCall, 1976). In this framework, higher benefits lead to higher reservation wages and lower search effort, since the opportunity cost of search is lower, which results in a drop in the exit rate from unemployment and to longer unemployment spells. Moreover, close to the time of benefit exhaustion the unemployment exit rate increases as the value of being unemployed drops, such that the

\footnotetext{
${ }^{7}$ Employment Protection Legislation (EPL) through firing costs might also have an effect on job duration and employment stability. However, the results are based on a comparison between recipients and nonrecipients in each country conditional on observed and unobserved heterogeneity, so any other institutional characteristics such as EPL are fixed.
} 
marginal benefit of search increases and the reservation wage falls leading to a higher exit rate (Mortensen, 1977; Meyer, 1990).

This disincentive effect of UI has been the conventional wisdom in modern labor economics. However, benefits can have an effect not only on unemployment duration but also on post-unemployment outcomes. There are two channels through which this effect on subsequent employment can operate.

The first focuses on the effect of UI on post-unemployment wages. Ehrenberg and Oaxaca (1976) were the first to consider the effect of UI on post-unemployment outcomes finding a positive effect of benefits on post-unemployment wages. More recently, Addison and Blackburn (2000) review the literature and provide results which suggest a weak effect of UI on re-employment wages. The second channel suggests that benefits have an effect on the subsequent employment duration by helping workers to get job which are compatible with their skills and therefore less likely to dissolve. Following Burdett (1979), unemployment benefits provide a "search subsidy" increasing the reservation wage and subsequent job quality. In particular, the unemployed without benefits might accept unsuitable jobs. On the other hand, generous benefits can make the unemployed very selective and reject matches which would have been socially efficient. Marimon and Zilibotti (1999) developed an equilibrium search-matching model in which UI has the standard effect of reducing employment, but also helps workers to get a relatively suitable job.

Other theoretical arguments based on the implicit contract literature suggest that UI can affect employment duration by inducing layoffs. The optimal response of a firm which faces demand fluctuations and firm specific human capital is to lay off workers with high level of UI entitlement and recall them back close to the time of benefit exhaustion (Feldstein, 1976).

The empirical literature on the effect of UI on re-employment duration is rather limited mainly due to the scarcity of large micro data sets with information both on labor market histories and UI benefits. This evidence is restricted to Canadian and US data. ${ }^{8}$

\footnotetext{
${ }^{8}$ Recently, Van Ours and Vodopivec (2006), investigate the effect of reducing the potential duration of unemployment benefits in Slovenia finding that it strongly increased job finding rates, but had no effect on the quality of post-unemployment jobs measured by the type of the contract, the duration of postunemployment jobs, or the wage earned.
} 
Belzil (2001), studies the effect of UI benefits on the exit rate from unemployment and subsequent employment using an inflow sample of unemployed from administrative files of the Canadian unemployment insurance program. He distinguishes between the "Matching" hypothesis and the "Adverse Selection" hypothesis. The first suggests that there is a positive correlation between the unemployment duration and subsequent job duration for benefit recipients, while the second refers to a spurious correlation between unemployment and subsequent job duration due to unobserved heterogeneity. His findings suggest that both hypotheses contribute to explain the observed correlation between unemployment duration and subsequent job duration. However, the effect of UI benefits is rather weak. In particular, he reports that increasing the maximum benefit duration by one week would raise expected unemployment duration by 1.0 to 1.5 days, but raise expected job duration by only 0.5 to 0.8 days.

Baker and Rea (1998), examine whether the requirements that workers must satisfy to become eligible for benefits in the future affect employment duration. Employing also Canadian data, they find a significant increase in the employment hazard in the week that an individual satisfies the eligibility requirement in many regions of the country. Jurajda (2002) looks also at the effect of future entitlement to UI benefits on the probability to exit employment using US data on labor market histories of displaced workers. Estimating a competing risks duration model he finds that being entitled to UI benefits significantly increases the layoff hazard. However, neither the length of potential UI entitlement, nor the benefit level affects the layoff hazard. Finally, the quit hazard is not affected by any of the UI system parameters.

Overall, the existing empirical evidence from the US and Canada has found a weak positive effect of UI on subsequent job duration (Belzil, 2001), and an effect of eligibility to UI on employment hazard (Baker and Rea, 1998), which mainly operates through an increase in layoffs (Jurajda, 2002).

\section{The Data}

The analysis is based on individual data from the European Community Household Panel (ECHP, 1994-2001). The ECHP is a survey based on a standardized questionnaire with annual interviewing of a representative panel of households and individuals in each 
country, covering a wide range of topics including demographics, employment characteristics, education etc. In the first wave, a sample of some 60,500 households approximately 130,000 adults aged 16 years and over - were interviewed in the then 12 Member States. There are three characteristics that make the ECHP relevant for this study. The simultaneous coverage of employment status, the standardized methodology and procedures yielding comparable information across countries and the longitudinal design in which information on the same set of households and persons is gathered. The countries studied are Denmark, France, Germany, Greece, Ireland, Italy, Spain, and the $\mathrm{UK}^{9}$

Using the calendar of activities for the years 1994-2001, which provides monthly information about the labor market status in the previous year, individual labor market histories are constructed up to December 2000. The sample consists of an inflow of individuals in unemployment out of employment. That is, all sampled unemployed are exiting an ongoing employment spell. The analysis is focused on males, because of their higher attachment to the labor market, aged 20-60 years old, and allows for multiple spells of unemployment and subsequent employment.

Unemployment spells can end in one of the following two ways: by re-entering employment, or by exiting the labor force. Unemployment spells that last longer than the end of 2000, which is the last observation in the calendar, are treated as right censored. Transitions from unemployment to employment are considered as completed spells, while transitions from unemployment out of the labor force are considered as continued unemployment spells. Those unemployed who exit the labor force can either become employed, re-enter unemployment, or remain out of the labor force. That is, the duration of unemployment for those who have been out of the labor force is the sum of the duration of the initial unemployment spell and the duration of the spell out of the labor force. $^{10}$

\footnotetext{
${ }^{9}$ Countries that are not considered in the analysis include the Netherlands and Sweden, as the information from the calendar of activities is not reported, as well as Austria, Belgium, Finland, and Portugal, due to small sample sizes.

${ }^{10}$ Exits from unemployment to inactivity are considered as continued unemployment spells since the majority of those unemployed who exit to inactivity re-enter either unemployment or enter directly into employment. The alternative is to treat those who exit to inactivity as right censored unemployment spells. In Section 5 the sensitivity of the results is discussed based on estimating the model under this alternative assumption.
} 
Transitions in the sample are depicted in Table 1 with the first column showing the number of unemployment spells observed for each country. Between 63 percent, for Germany, and 78 percent, for Greece, of these unemployment spells end into employment. The third column depicts the share of those employment spells which end back into unemployment. This varies from 27 percent, in the U.K., to 63 percent in Greece. For Italy, Spain, and Greece, the percentage of employment spells which end into unemployment is much higher. These are also countries with unemployment rate above the European average.

\subsection{Description of Data on Unemployment Insurance}

\subsubsection{Benefit Indicator}

The empirical analysis is based on a comparison between benefit recipients and non-recipients in each country. This is similar to the study by Bover, Arellano, and Bentolila (2002), who investigate the effect of benefits on unemployment duration in Spain, but contrary to many other studies which identify the effect of benefits by using variation on the level and potential duration of benefits. The reason for following this strategy is that information on unemployment benefits in the ECHP is rather limited and is based on two main sources. The first refers to the question on whether an unemployed receives benefits at the time of the interview. The second refers to the amount of benefits received during the year which can only be used to infer receipt of benefits when the first measure is not available. ${ }^{11}$ Therefore, both these sources are considered to determine whether an unemployed receives benefits during a spell. This is particularly relevant for short spells. Relying only on whether an unemployed receives benefits at the time of the interview can be uninformative for short spells given that they might not coincide with the time of any interview.

\subsubsection{Benefit Duration}

As mentioned above, the ECHP contains no information on benefit duration. Following Bover, Arellano, and Bentolila (2002), a measure of benefit duration is

\footnotetext{
${ }^{11}$ This information cannot be used to construct the benefit level for a particular unemployment spell as an individual might be unemployed twice during a year.
} 
constructed using the two available sources of information on benefits and the unemployment duration. This constructed benefit duration variable coincides with unemployment duration for those who still receive benefits at the end of unemployment spell. That is, benefit duration is censored although this censoring is of a different kind compared to the censoring of unemployment duration. Those who have exhausted their benefits can be identified by combining the information on the receipt of benefits with the amount of benefits. Therefore, the data are asymmetric in the two durations and a monthly benefit indicator variable $I\left(t_{b} \geq t_{u}\right)$ is constructed, which is equal to 1 if $t_{b} \geq t_{u}$, that is, if unemployed still receive benefits, and zero otherwise, where $t_{b}$ refers to benefit duration and $t_{u}$ to unemployment duration. ${ }^{12}$

\subsection{Descriptive Statistics}

By relying on non-experimental data, those who are observed to receive benefits are not expected to be a random group. Table 2 shows summary statistics of unemployment spells in the sample. The first column for each country refers to those receiving benefits during unemployment, while the second refers to non-recipients. It turns out that there is variation across countries in the share of unemployed receiving benefits which reflects the different eligibility criteria that apply to each country. It is the feature of the data that provides this variation in the receipt of benefits since an inflow sample into unemployment is drawn from a representative survey of the population. It is usually in administrative data the case in which non-recipients are a minority with certain characteristics, such as seasonal workers. Nevertheless, it is expected that the receipt of benefits is associated with certain individual characteristics. In particular, benefit recipients tend to be less educated, older, more likely to be married with more children and spouses who are non-employed. Moreover, they experience longer average unemployment duration than non-recipients. Apart from this observed heterogeneity recipients might differ with non-recipients with respect to other characteristics which are unobservable. The way to address this heterogeneity in the data is discussed in the next section which describes the statistical model.

\footnotetext{
${ }^{12}$ For more on the construction of the benefit indicator and benefit duration variables see Appendix B.
} 


\subsection{Kaplan-Meier Survivor Functions}

A preliminary analysis for the effect of UI based on the Kaplan-Meier survivor functions for recipients and non-recipients is presented in Table 3. The first panel, which refers to the unemployment spells, indicates that the percentage of recipients who are still unemployed after 12 months is higher compared to non-recipients. For instance, 48 per cent of recipients in France are still unemployed after 12 months compared to 36 per cent for non-recipients. The survival rate after 12 months for recipients vs. non-recipients for Germany is 49 per cent vs. 28 per cent, for Ireland 36 per cent vs. 20 per cent, for Spain 31 per cent vs. 22 per cent, and for the UK is 43 per cent vs. 26 per cent. It is only for Greece and Italy that the percentage of those surviving after 12 months is lower for recipients compared to non-recipients. The second panel of Table 3 depicts the survival rate for employment spells stratified by benefit receipt during the previous unemployment spell. After 12 months in employment, the percentage of those who survived is higher for previously unemployed recipients in Denmark, France, and Germany.

However, as previously noted, such analysis of employment histories might be misleading. First, the sample of recipients and non-recipients is not randomly drawn so that a simple comparison between their survival rates may be confounded by individual characteristics associated with the receipt of benefits. Moreover, the subsample of recipients and non-recipients who experience an employment spell are also not randomly drawn, as there might be specific observed and unobserved characteristics that can be correlated across the two spells. To address these issues a statistical model is required that takes into account the endogeneity of benefits and controls for correlated unobserved heterogeneity across unemployment and employment spells.

\section{Econometric Model}

To estimate the effect of unemployment benefits on unemployment and subsequent employment both transitions are modeled. The econometric framework is a multivariate mixed proportional hazard model. In line with most applications analysing individual's labour market transitions, a reduced-form approach is adopted. Before describing the 
econometric specification an econometric issue which concerns the endogeneity of the benefit receipt variable needs to be addressed. As described section 3, what can be observed in the data is a time-varying dummy variable for benefits denoted as $b(t)=I\left(t_{b} \geq t_{u}\right)$, where $t_{u}$ denotes unemployment duration, and $t_{b}$ denotes benefit duration. This variable indicates whether an individual receives benefits at each month during the unemployment spell. For non-recipients $\left(t_{b}=0\right)$ and for those who have exhausted their benefits before the end of the unemployment spell $\left(t_{b}<t_{u}\right)$, the indicator variable $b(t)$ is equal to zero. For those who still receive benefits i.e. $\left(t_{b} \geq t_{u}\right)$, the benefit variable $b(t)$ is equal to one. In the model, $b(t)$ is a predetermined variable as opposed to strictly exogenous since the probability of exiting unemployment can be conditioned on the path of $b(t)$ up to $t$, but not on $b(t+1), \quad b(t+2)$, etc., as the entire path of benefit duration is not observed. Following the detailed discussion in Bover, Arellano and Bentolila (2002), $b(t)$ becomes endogenous when considering models with unobserved heterogeneity. Allowing for unobserved heterogeneity might be important as the benefit indicator may be correlated with these unobserved factors, such as human capital variables, or preferences.

The hazard function for unemployment and employment spells is modelled in discrete time, since the labor market status is observed in monthly intervals, using the logistic function as in Bover, Arellano and Bentolila, (2002), Ham and LaLonde (1996), and Meyer (1990), among others. Denote with the vectors $X_{u i k}$ and $X_{\text {eik }}$ personal characteristics and economic variables which refer to the year the spell started, and therefore are fixed within a spell, but are allowed to vary across spells. Among the personal characteristics are age dummies, education dummies (defined using the ISCED classification), whether or not the individual is married, the number of children, and whether the spouse is not employed. The vector $X_{\text {eik }}$ includes also whether or not the employment is in a part time job. The economic variables include the regional unemployment rate at the time of entering unemployment or employment, respectively. The unobserved heterogeneity is represented by a scalar random variable $\theta_{j i \text {. The hazard }}$ 
is conditioned on the $X_{i}$ variables, but for notational ease in what follows this conditioning becomes implicit.

The transition for person $i$ for a spell $k$ is defined as follows:

$$
\lambda_{j i k}\left(t_{k} \mid \theta_{j i_{k}}\right)=P\left[T_{j i k}=t_{j i k} \mid T_{j i k} \geq t_{j i k}, \theta_{j i_{k}}\right]=F\left(y_{j i k}\right)
$$

where $F$ is the logistic cumulative distribution function: $F(u)=e^{u} /\left(1+e^{u}\right)$, and $y_{j i k}$ for the unemployment spell, where $j=u$, is defined as:

$$
y_{u i k}=\beta_{0 u}+\beta_{1 u} X_{u i k}+\delta_{u} b_{k}(t)+\sum_{d=1}^{4} \beta_{2 u} I_{d}(t)+\theta_{u i}
$$

For the employment spell $y_{\text {eik }}$ is defined as:

$$
y_{e i k}=\beta_{0 e}+\beta_{1 e} X_{e i k}+\delta_{1 e} b_{e k}+\sum_{d_{u}=1}^{3} \delta_{2 e} \tau_{d u k}+\sum_{d=1}^{4} \beta_{2 e} I_{d}(t)+\theta_{e i}
$$

The dummy variable $b_{k}(t)$ in equation (2) equals to one when an individual receives benefits at a certain month in a spell $k$, and 0 otherwise. The specification in equation (3) includes the dummy $b_{e k}$ which denotes whether the individual received benefits during the previous unemployment spell, and a set of interval dummies for previous unemployment duration $\tau_{d u k}$, where $d_{u}=(1,2,3)$ and $d_{u}=1$ denotes duration of 1-6 months, $d_{u}=2$ of 7-12 months, and $d_{u}=3$ of more than 12 months. ${ }^{13}$

The effect of duration dependence is modelled by using time dummy variables denoted as $I_{d}(t)$, which are equal to one when duration $t$ is within the duration intervals as denoted by the subscript $d=(1,2,3,4)$. These intervals are defined as, $d=1$ for 1-6 months of duration, $d=2$ for 7-12 months, $d=3$ for 12-24 months, and $d=4$ for more than 24 months. Since there is a constant included in the model the first interval is normalized to zero.

Using the transition rates in equation (1) the contribution of the unemployment and employment spells to the likelihood can be defined for each individual for a given spell.

\footnotetext{
${ }^{13}$ These intervals are chosen in order to reflect the distinction between short and long term unemployed, as they are usually defined. For estimation, the reference group is duration more than 12 months. In section 5.3, another specification is discussed in which interval dummies for previous unemployment duration and their interaction with the benefit dummy are included to capture possible heterogeneity effects of benefits.
} 
The contribution of a completed unemployment and employment spell conditional on $\theta_{j i .}$ is given by ${ }^{14}$

$$
f_{j}\left(t_{j} \mid \theta_{j}\right)=\lambda_{j}\left(t_{j} \mid \theta_{j}\right) \prod_{s=1}^{t_{j}-1}\left(1-\lambda_{j}\left(s \mid \theta_{j}\right)\right)
$$

while the contribution of a censored spell is given by

$$
S_{j}\left(t_{j} \mid \theta_{j}\right)=\prod_{s=1}^{t_{j}}\left(1-\lambda_{j}\left(s \mid \theta_{j}\right)\right)
$$

To account for endogeneity of benefits a logistic process for benefits is specified along the lines suggested by Bover, Arellano and Bentolila (2002), as follows:

$$
\lambda_{\text {bik }}\left(t_{k} \mid \theta_{u i_{k}}\right)=P\left[b_{k}(t)=1 \mid b_{k}(t-1)=1, T_{u i k} \geq t_{u i k}, \theta_{u i_{k}}\right]=F\left(y_{b i k}\right)
$$

where $F$ is the logistic cumulative distribution function, $b_{k}(1)=1$ for every spell, and

$$
y_{b i k}=\beta_{0 b}+\beta_{1 b} X_{b i k}+\sum_{d=1}^{4} \beta_{2 b} I_{d}(t)+\theta_{b i}
$$

The vector $X_{b i k}$ includes the same characteristics as for the unemployment spell. During the first month, the equation refers to the probability of receiving benefits once becoming unemployed, while in subsequent months it refers to the probability of being entitled to benefits having remained in unemployment up to that month and having received benefits in the previous month. ${ }^{15}$

Combining the contribution of completed and censored unemployment spells with the logistic process for benefits, the likelihood for the unemployment spells can be written as:

$$
L_{u}=\int\left(\left[f_{u}\left(t_{u} \mid \theta_{u}\right)\right]^{c_{u}}\left[S_{u}\left(t_{u} \mid \theta_{u}\right)\right]^{1-c_{u}}\right)\left[f_{b}\left(t_{u} \mid \theta_{b}\right)\right]^{b_{u}} d G\left(\theta_{u}, \theta_{b}\right)
$$

where $f_{b}\left(t_{u} \mid \theta_{b}\right)$ is defined using equations (1), (6), and (7), while $b_{u}$ is a dummy which equals to one for recipients and zero for non-recipients. The likelihood for the employment spell is given by

\footnotetext{
${ }^{14}$ In what follows the $i$ and $k$ subscripts are dropped.

${ }^{15}$ Identification of the benefit equation is achieved with multiple spells through variation of benefit receipt for the same individual across different observed spells.
} 


$$
L_{e}=\int\left[f_{e}\left(t_{e} \mid \theta_{e}\right)\right]^{c_{e}}\left[S_{e}\left(t_{e} \mid \theta_{e}\right)\right]^{1-c_{e}} d G\left(\theta_{e}\right)
$$

The dummy variables $c_{u}$ and $c_{e}$ equal to one, if the spell is completed, and to zero if the spell is censored for unemployment and employment spells, respectively. Therefore, the total contribution to the likelihood for each individual is given by

$$
L=\int L_{u} L_{e} d G\left(\theta_{u}, \theta_{b}, \theta_{e}\right)
$$

Following Heckman and Singer (1984), the unobserved heterogeneity distribution is defined as a discrete distribution with the support points denoted by $\varepsilon_{j p}$ and the corresponding probability mass given by $\operatorname{Pr}\left(\varepsilon_{j}=\varepsilon_{j p}\right)=\pi_{j p}$, where $P$ denotes the number of support points. Each unobserved factor is assumed to be time invariant and individual specific. That is, it is assumed to be the same across multiple spells of unemployment, or employment. However, as is discussed below, the unobserved factors are allowed to be different and correlated across unemployment and employment spells. Identification of a multi-spell mixed proportional hazard model is achieved under weaker assumption than a single-spell mixed proportional hazard model, see Honore (1993). In particular, no assumptions about the mixing distribution are needed with a fixed heterogeneity distribution over spells, although the proportionality assumption between the unobserved heterogeneity term and the duration effect must be preserved. Van den Berg (2001) provides a detailed discussion of identification issues of the mixed proportional hazard model.

The model of unemployment and employment hazard is estimated jointly by maximum likelihood taking into account the endogeneity of benefits and allowing for correlation between the unobserved factors in each equation. Assuming a discrete distribution with two points of support for each of $\varepsilon_{u}, \varepsilon_{b}$, and $\varepsilon_{e}$, and perfect correlation between them, the individual likelihood can be written as follows: ${ }^{16}$

$$
L=\left(L_{u}\left(H_{u} \mid \varepsilon_{u 1}, \varepsilon_{b 1}\right) L_{e}\left(H_{e} \mid \varepsilon_{e 1}\right)\right) \cdot \pi_{1}+\left(L_{u}\left(H_{u} \mid \varepsilon_{u 2}, \varepsilon_{b 2}\right) L_{e}\left(H_{e} \mid \varepsilon_{e 2}\right)\right) \cdot\left(1-\pi_{1}\right)
$$

\footnotetext{
${ }^{16}$ In the empirical application with unrestricted correlation the empirical results implied perfect correlation, hence perfect correlation was imposed in the final estimation.
} 
where $L_{u}$ and $L_{e}$ are defined in (8) and (9), respectively. Finally, the total likelihood is obtained by summing over all individual spells. In practice, unobserved heterogeneity is modelled by normalizing the first mass point to zero, since there is a constant in the specification, so that the estimated coefficient for the second mass point denotes deviation from the constant term.

\section{Empirical Results}

\subsection{Unemployment and Employment Hazard Estimates}

Starting the discussion of the results from the unemployment hazard estimates, Tables 4a and 4b (top panel) show that receiving unemployment benefits has a significant negative effect on the unemployment hazard in all countries. The exception is Ireland where there seems to be no effect. Simple comparison of the size of the coefficients across countries indicates that in countries with relatively less generous unemployment insurance, such as Italy and Greece, the effect on the unemployment hazard for recipients is smaller. ${ }^{17}$ The main results for the effect of other individual characteristics on unemployment hazard can be summarized as follows: ${ }^{18}$ unemployed who are above 50 years old (the reference age group) have lower exit rate from unemployment, while those who are more educated, married, and have more children, are in general more likely to leave unemployment. The positive effect of secondary and higher education on unemployment hazard is significant in France, Germany, Ireland, and Italy. For the U.K., a negative effect of secondary education on unemployment hazard is observed, which is significant only at the 10 per cent level, while for Greece and Denmark the effect is also negative, but not significant. The effect of business cycle, as this is captured by the regional unemployment rate at the time of entry into unemployment, shows that higher regional unemployment rate increases re-employment probabilities although the effect is insignificant, while there is a negative and significant effect for Italy.

\footnotetext{
${ }^{17}$ The comparison of the effect of unemployment benefits across countries based on the estimated expected unemployment duration is postponed to section 5.5.

${ }^{18}$ Each hazard function includes year dummies for the year entering in unemployment and employment, respectively.
} 
The bottom panel in Tables 4a and 4b contains the coefficient estimates for the employment hazard. The specification includes a dummy for having received benefits during the previous unemployment spell $\left(b_{e k}\right)$, and dummies for previous unemployment duration of length 1-6 and 7-12 months, respectively. The reference group refers to those employed with duration of previous unemployment of more than 12 months. The benefit coefficient indicates that recipients are less likely to exit subsequent employment. This effect is significant in all countries, except for Ireland and Greece. Controlling for the receipt of benefits, shorter previous unemployment experience is associated with lower hazard out of employment for France, Germany, and the U.K., although the coefficients are not significantly difference from zero. In Italy and Spain, short unemployment duration increases the hazard from subsequent employment. The results for other characteristics can be summarized as follows: more educated, younger, married, and fulltime workers are less likely to exit employment. The age effect seems to be reversed for France, and Greece. For France, in particular, a large positive effect on employment hazard is observed for the age group 20-24 years old. One effect that is worth noticing is that of regional unemployment rate at the time of entering employment. The coefficient is positive and significant for Germany, Italy, and Spain. This indicates a business cycle effect in which employment stability is worse in thin markets.

The results presented in Table $4 \mathrm{a}$ and $4 \mathrm{~b}$ are based on an inflow sample of unemployed with the spells who exit into inactivity being treated as continued unemployment spells. To evaluate the sensitivity of this sampling strategy the model was estimated considering the spells who exit to inactivity as right censored unemployment spells. Table A3 in the appendix contains the coefficient of the benefit dummy for both equations. The coefficients and statistical significance both in the unemployment and the employment hazard are similar with the results shown in Table $4 \mathrm{a}$ and $4 \mathrm{~b} .{ }^{19}$

Finally, the coefficients estimates of the benefit receipt equation are reported in Table A.2 in the appendix. During the first month the equation refers to the probability of receiving benefits once becoming unemployed, while in subsequent months it refers to

\footnotetext{
${ }^{19}$ The only exception is the benefit coefficient in the unemployment equation for the U.K which drops from -0.721 in Table $4 \mathrm{~b}$ to -0.411 in Table A3. However, the benefit effect in the employment equation is not different between the two models. Given the lack of generosity of the U.K. UI system, quite likely the unemployment effect of benefits in the U.K is lower than the one of Table $4 \mathrm{~b}$.
} 
the probability of being entitled to benefits having remained in unemployment up to that month and having received benefits in the previous month. These probabilities depend on the eligibility rules for unemployment insurance and unemployment assistance and the provision of the UI system in terms of benefit duration. Given the complexity of the rules, and since this equation is just an auxiliary reduced-form, there is no attempt to provide an interpretation of these coefficients.

\subsection{Heterogeneity Effects of Benefits across Education Groups}

From the above analysis it appears that unemployment benefits not only increase the duration of unemployment spells but also the stability of subsequent employment. Moreover, education matters, with more educated unemployed finding easier to leave unemployment and entering into more stable employment. If lower educated unemployed face more difficulties returning into stable employment, to what extent the effect of benefits is heterogeneous across education groups? This can be answered by allowing for an interaction effect of the benefit dummy, in both equations, with education. Table 5 gives the estimated coefficients of the main effect and its interaction with high and medium education. For the unemployment equation the interaction effects are not significantly different than zero. This indicates that there is no heterogeneity in the effect of benefits across education groups in unemployment. It is only for those with medium education in Spain that is found some weakly positive effect of benefits on the unemployment hazard. For the employment equation, recipients with high education in Germany have higher hazard rate than recipients with less than high education. This indicates that there is heterogeneity in the effect of benefits on employment stability, with benefits being more beneficial in terms of employment stability for less educated workers. The opposite holds in Denmark, where the negative effect of benefit receipt on employment hazard is mainly for highly educated workers. Finally, in Spain and the U.K, the negative effect of benefit receipt is observed to be higher for those with more than low education. 


\subsection{Heterogeneity Effects of Benefits by Previous Unemployment Duration}

Another specification was estimated in which the dummy for having received benefits in the employment equation is interacted with previous unemployment duration. The motivation is to identify any heterogeneity effect of benefits for different unemployment experiences. Staying longer in unemployment might not only improve job matching but may also create a scarring effect through skill obsolescence.

The estimates for the employment hazard equation are reported in Table 6, where an interaction of the benefit dummy with unemployment duration of length between 1-6 months is introduced. ${ }^{20}$ The main effect of benefit receipt on employment hazard rate does not change compared to the specification without the interaction term. The interaction term appears positive, but significant only in Germany, indicating a higher exit rate for recipients with 1-6 months of unemployment in comparison to those above 7 months. That is, the effect of benefits in reducing the employment hazard is higher for those who have remained unemployed for more than 6 months.

Finally, the model was estimated allowing for an additional interaction of benefits with previous unemployment duration of length between 7-12 months. For Denmark, and Spain, both these interaction terms are positive and significant, while for Ireland only the interaction term with 1-6 months of previous unemployment is positive and significant at 10 per cent significance level. ${ }^{21}$ These results suggest that also in these countries receiving benefits reduces the exit from subsequent employment for those with longer unemployment duration. In section 5.5 is presented a more comparable measure of the effect of benefits by previous unemployment duration based on estimated expected durations.

\subsection{Duration Dependence and Unobserved Heterogeneity}

As described in section 4, the model is estimated jointly allowing for correlated unobserved heterogeneity across unemployment and employment spells. This is important as certain unobserved characteristics, such as motivation and preferences, may

\footnotetext{
${ }^{20}$ The estimates for the unemployment hazard and for the other characteristics in the employment equation are not reported as they are similar to those in Tables 4a, 4b.
} 
affect both the entry and exit rate from employment leading to spurious correlation. In addition, controlling for unobserved heterogeneity allows to distinguish between true and spurious duration dependence. Spurious negative duration dependence in unemployment arises when those with more favorable labor market characteristics leave unemployment earlier, such that the remaining pool of unemployed consists of individuals with lower chances of moving into employment.

Table 7 reports the coefficient estimates for duration dependence in both unemployment and employment hazard functions and the unobserved heterogeneity distribution, which includes the mass point estimates from the auxiliary benefit equation. The reference category in the duration dependence coefficients is duration between 1 to 6 months. For the discrete unobserved heterogeneity two mass points are allowed in each equation normalizing one to zero since there is a constant term in the vector of covariates. The second mass point can be interpreted as the deviation from the first. Perfect correlation ( -1 or 1 ) is assumed between the two points of support with a mixing distribution that has a logit specification. This means that conditional on observed characteristics and the time spent in the current spell there are two types of individuals that differ in their unemployment hazard (high/low), their employment hazard (high/low), and the probability to receive benefits (high/low).

In the unemployment equation, the existence of negative duration dependence is observed in all countries. The negative effect on the hazard out of unemployment is larger the longer the time spent in unemployment. In the employment equation, there is a non-linear relationship between duration and the hazard rate. In particular, in Germany, Greece, and Italy, workers in employment for 6 to 12 months are more likely to exit, compared to those with less than 6 months. For the rest of the countries the effect is not significant. However, those who remain employed for more than 12 months are less likely to exit employment. In Denmark and Germany, negative duration dependence is significant for durations above 24 months.

Finally, Table 7 shows the coefficient estimates of the unobserved heterogeneity distribution. With two mass points allowed in each equation there are six parameter estimates. The coefficients of the second mass point, which denote deviation from the

\footnotetext{
${ }^{21}$ These estimation results are not reported and are available from the author upon request.
} 
first mass point, show that in each country there is a group which has a higher exit rate both from unemployment and employment. ${ }^{22}$ The probability of the type with high exit rate from unemployment and employment is about 65 to 70 per cent for Denmark, France, Germany, while it varies from 20 per cent in Italy, to 30 in Greece, and 50 per cent in Spain.

\subsection{Expected Durations}

To obtain the magnitude of the effect of benefits, the average unemployment and employment expected duration is computed distinguishing between the two different types of individuals based on the unobserved heterogeneity terms that have been identified. ${ }^{23}$ Table 8 a shows the expected durations based on the estimates from Tables $4 \mathrm{a}$ and $4 \mathrm{~b}$. The expected unemployment duration for recipients is larger than non-recipients. The difference varies from 4.5 months in Germany, to 3.8 months in France, 2-2.5 months in Spain and the U.K., and about 1.5 months in Denmark and Ireland. The difference in expected unemployment duration between recipients and non-recipients appears to be larger in countries with more generous unemployment insurance systems, such as Germany, and France.

The expected employment duration depicted also in Table 8a shows that for Denmark, France, Germany, and Spain, the expected employment duration of recipients is higher than that of non-recipients. The positive difference varies from 1.3 months for Type A individuals in Denmark, to 2.7 months for Type B individuals in Germany, while it is less than a month in Spain. In contrast, for Greece, Ireland, Italy, and the U.K., the expected employment duration of recipients is lower than that of non-recipients. The negative difference in these countries varies from about 4.5 months longer employment

\footnotetext{
${ }^{22}$ In some countries one of the mass points in the benefit equation appeared to be very small. This can be caused by the small variation in the time varying benefit indicator. The time variation is achieved by benefit recipients exhausting benefits before exiting unemployment. In the estimation this parameter was fixed to minus infinity.

${ }^{23}$ The mean expected duration can be computed as $E_{j}(t \mid X, \varepsilon)=I^{-1} \sum_{i=1}^{I} \sum_{t=1}^{\infty} t L_{j}\left(t \mid x_{j i t}, \varepsilon_{j}\right)$, where $L_{j}\left(t \mid X_{j i k t}, \varepsilon_{j}\right)$ denotes the unconditional probability of leaving state $j$ at duration $t$, and where $I$ is the number of spells in a sample, $x_{j i t}$ is the vector of all explanatory variables for a spell $i$ at duration $t, X$ denotes the collection of all $X_{j i t}$ vectors, and $\varepsilon_{j}$ denotes the unobserved term.
} 
duration for non-recipients in Greece, to about 3.8 in Italy, and about 1.2-1.5 months in Ireland, and the U.K.

Table $8 \mathrm{~b}$ shows the expected employment durations by the length of previous unemployment duration, based on the estimates from Tables 6 where the effect of benefits by previous unemployment duration was estimated. In Germany, the expected employment duration difference between recipients and non-recipients for unemployed less than 6 months, which are denoted as (UD 1-6), is about 2.3 months and increases to more than 4 months for those unemployed for more than 6 months, denoted as (UD $6^{+}$). That is, the penalty in terms of subsequent employment for remaining longer in unemployment is lower for recipients, indicating a matching effect of benefits. For Spain, it is also observed an increase in the expected employment duration difference between recipients and non-recipients, for those with longer previous unemployment duration, of about 3 months. For France, there is no change in the employment duration difference between the two groups as they search for longer period while unemployed. This could be related to the decreasing UI payment rate rule at every 4 monthly intervals, which was active during the period of the analysis, so that staying longer in unemployment was associated with a penalty in terms of the level of benefits received. For the U.K. and Ireland, the difference of the expected employment duration between recipients and nonrecipients is negative for (UD 1-6), while it becomes positive for (UD 6+), but small (1 month for the U.K.). Note that in the U.K., the duration of unemployment insurance is 6 months followed by unemployment assistance. That is, higher employment stability is observed for recipients who exhaust their unemployment insurance benefits and possibly receive unemployment assistance afterwards. Finally, in Denmark the expected employment duration of non-recipients exhibits a larger decline as unemployment duration increases, relative to the one of recipients. This leads to a large increase in the difference of expected employment duration between recipients and non-recipients. However, due to small sample size in Denmark, this large decline should be seen with some caution.

This analysis shows that there are three different groups of countries. The first group consists of countries with relatively generous benefits (Denmark, France, Germany), and Spain, in which recipients experience longer employment duration 
compared to non-recipients, and the effect is higher for those who remained unemployed for at least 6 months. The magnitude of the effect is about 2 to 4 months longer employment spells compared to non-recipients, which represents a 10 to 20 per cent increase relative to the average expected employment duration. This increase compensates for the longer unemployment period (except in France), which suggests that the net impact is non-negative. The second group consists of the Anglo-Saxon countries, (Ireland and the U.K.), who provide a flat rate payment for the unemployed for a relative short period (6 months in the U.K.). Recipient's employment duration is lower than nonrecipient's (negative difference), while this difference turns to positive for those who remained unemployed for more than 6 months. The third group of countries (Greece and Italy), has a rather underdeveloped UI system and the expected employment duration for recipients is lower compared to non-recipients.

\section{Conclusions}

This paper investigated the effect of UI both on unemployment duration and subsequent employment stability for eight European countries using individual data from the European Community Household Panel (ECHP, 1994-2001). Estimating a multivariate discrete hazard model, taking into account observed and unobserved individual heterogeneity, it is found that depending on the characteristics of the system in place, UI can be a mixed blessing. Although benefit recipients experience longer unemployment spells, there is also a positive effect of UI on subsequent employment stability.

The countries analysed can be distinguished between those with relatively generous UI system (Denmark, France, Germany), the Anglo-Saxon countries (Ireland and U.K.) with flat rate payments and relatively short benefit duration, and the South European countries (Italy and Greece), in which the system is rather underdeveloped. The increased employment duration for recipients is found for the first group of countries, and Spain, which provides more generous benefits compared to southern group. The effect is found to be larger for recipients who have stayed unemployed for at least 6 months. In terms of the magnitude of the effect, recipients remain employed on average 2-4 months 
longer compared to non-recipients, which represents a 10-20 per cent increase relative to the average employment duration. This in most cases (Denmark, Germany, and Spain) offsets the direct effect of benefits through longer periods in unemployment, which means that the net effect is non-negative.

These empirical findings of an indirect effect of UI are in line with theories suggesting a matching effect of UI. As it turns out, this indirect effect is pronounced in countries with more generous benefits. Although firm conclusions cannot be drawn regarding the "optimal" level of UI, these findings suggest that future research should consider both the direct and indirect effects of UI in designing an optimal UI system. From a policy point of view, these results indicate that recommendations aimed at removing the disincentive, or direct, effect of UI by reducing the generosity of the UI system might not be compatible with the goal of achieving higher employment in Europe. 


\section{References}

Addison, J.T. and M.L. Blackburn (2000): "The Effects of Unemployment Insurance on Postunemployment Earnings", Labour Economics, 7, pp. 21-53.

Atkinson, A. and J. Micklewright (1991): "Unemployment Compensation and Labor Market Transitions: a critical review", Journal of Economic Literature, 29, pp. 1679-1727.

Baker, M. and S.A. Rea (1998): "Employment Spells and Unemployment Insurance Eligibility Requirements", Review of Economics and Statistics, 80, pp. 80-94.

Belzil, C. (2001): "Unemployment Insurance and Subsequent Job Duration: job matching vs. unobserved heterogeneity", Journal of Applied Econometrics, 16:5, pp. 619-636.

Bertola, G., J.F. Jimeno, R. Marimon, and C. Pissarides (2000): "EU Welfare Systems and Labour Markets: Diverse in the Past, Integrated in the Future?" in: Bertola, G., Boeri, T., Nicolleti, G. (Eds.), Welfare and Employment in a United Europe, MIT Press, Cambridge.

Bonnal, L., D. Fougere and A. Serandon (1997): "Evaluating the Impact of French Employment Policies on Individual Labour Market Histories", The Review of Economic Studies, 64, pp. 683-713.

Bover, O., M. Arellano and S. Bentolila (2002): "Unemployment Duration, Benefit Duration and the Business Cycle", Economic Journal, 112, pp. 223-265.

Burdett, K. (1979): "Unemployment Insurance Payments as a Search Subsidy: a theoretical analysis", Economic Inquiry, 42, pp. 333-343.

Card, D.E. and P.B. Levine (2000): "Extended Benefits and the Duration of UI Spells: Evidence from the New Jersey Extended Benefit Program", Journal of Public Economics, 78, pp. 107-138.

Devine, J. and N. Kiefer (1991): "Empirical Labor Economics", Oxford University Press, Oxford.

Ehrenberg, R.G. and R.L. Oaxaca (1976): "Unemployment Insurance, Duration of Unemployment and Subsequent Wage Gain", American Economic Review, 66:5, pp. 754-776.

Feldstein, M.S. (1976): "Temporary Layoffs in the Theory of Unemployment", Journal of Political Economy, 84, pp. 837-857.

Gritz, R.M. (1993): "The Impact of Training on the Frequency and Duration of Employment", Journal of Econometrics, 57, pp. 21-51.

Ham, T. and R. Lalonde (1996): "The Effect of Sample Selection and Initial Conditions in Duration Models: Evidence from Experimental Data on Training", Econometrica, 64, pp.175-205.

Ham, J.C. and S.A. Rea (1987): "Unemployment Insurance and Male Unemployment Duration in Canada", Journal of Labor Economics, 5, pp. 325-353.

Heckman, J.J. and B. Singer (1984): "A Method for Minimizing the Distributional Assumptions in Econometric Models for Duration Data", Econometrica, 52, pp. 271-320. 
Jurajda, S. (2002): "Estimating the Effect of Unemployment Insurance Compensation on the Labor Market Histories of Displaced Workers", Journal of Econometrics, 108, pp. 227-252.

Lippman, S.A. and J.J. McCall (1979): "Studies in the Economics of Search" NorthHolland, Amsterdam.

Katz, L.F. and B.D. Meyer (1990): "The Impact of the Potential Duration of Unemployment Benefits on the Duration of Unemployment", Journal of Public Economics, 41(1), pp. 45-72.

Lalive, R. and J. Zweimüller (2004): "Benefit Entitlement and Unemployment Duration: Accounting for Policy Endogeneity", Journal of Public Economics, 88(12), pp. 2587-2616.

Marimon, R. and F. Zilibotti (1999): "Unemployment vs. Mismatch of Talents: reconsidering unemployment benefits", Economic Journal, 109, pp. 266-291.

Meyer, B. (1990): "Unemployment Insurance and Unemployment Spells", Econometrica, 58, pp. 757-782.

MISSOC (1994): "Social Protection in the Member States of the European Union", European Commission, Directorate-General for Employment Industrial Relations and Social Affairs.

Mortensen, D. (1977): "Unemployment Insurance and Job Search Decisions", Industrial and Labor Relations Review, 30, pp. 505-517.

Nickell, S.J. and R. Layard (1999): "Labor Market Institutions and Economic Performance", in: Ashenfelter, O. and Card, D. (Eds.), Handbook of Labor Economics, Vol 3, North-Holland, Amsterdam, pp. 3029-3084.

OECD (1996): "Employment Outlook", Chapter 2, Paris.

OECD (1998): "Benefits Systems and Work Incentives", Paris.

OECD (2002): "Benefits and Wages", Paris.

Van de Berg, G. J. and G. Ridder (1998): "An Empirical Equilibrium Model of the Labor Market", Econometrica, 66, pp. 1183-1221.

Van de Berg, G. J. (2001): "Duration Models: Specification, Identification, and Multiple Durations", in: Heckman, J. and Leamer, E. (Eds.), Handbook of Econometrics, Vol. V, North-Holland, Amsterdam, pp. 3381-3460.

Van Ours, J.C. (2001): "Do Active Labor Market Policies Help Unemployed Workers to Find and Keep Regular Jobs?", in: Lechner, M. and Pfeiffer, F. (Eds.), Econometric Evaluation of Labour Market Policies, Physica-Verlag, pp. 125-152.

Van Ours, J.C. and M. Vodopivec. (2006): "Shortening the Potential Duration of Unemployment Benefits Does not Affect the Quality of Post-Unemployment Job: Evidence from a Natural Experiment", IZA Discussion Paper No. 2171.

Wooldridge, J.M. (2002): "Econometric Analysis of Cross Section and Panel Data", MIT Press, Cambridge. 


\section{Appendix A: Description of the Unemployment Insurance System across Countries}

Table A1 shows the main characteristics of the UI system for the eight countries analyzed in this study. There are mainly two schemes of unemployment benefits, unemployment insurance, and unemployment assistance. Unemployment insurance is the main scheme under which those who are eligible receive compensation in the event of entry into unemployment. Eligibility is based upon previous employment and contribution histories, which implies that it does not cover all the unemployed. Unemployment assistance is not available in all countries. It is generally means tested and it is usually available for those who exhaust unemployment insurance and those who are not eligible. We do not distinguish between unemployment insurance and assistance as this distinction is not observed in our data. Following Bertola et.al., the countries in our study can be classified as follows: 1) the Nordic (Denmark) and the Continental countries (France, and Germany) which provide generous benefits, 2) the Anglo-Saxon countries (United Kingdom and Ireland) which provide flat rate payments with relatively short duration, and 3) the southern European countries (Greece, Italy, and Spain) which have welfare states that were developed recently and provide limited unemployment insurance, although Spain resembles more to the Continental countries.

\section{Appendix B: Construction of Benefit Variables}

\section{B.1. Construction of the Benefit Indicator}

We construct the benefit indicator using the two sources of information available at the ECHP, that is, whether receiving benefits if unemployed at the time of the interview, and the amount of benefits received during the year. By relying only on whether an unemployed receives benefits at the time of the interview can be uninformative for short spells given that they might not coincide with the time of any interview. For instance, for spells of type $\mathrm{C}$ in Figure 1, which are long enough to reach the time of the next interview, the information on receipt of benefits at the time of the next interview is used. However, this source of information is not sufficient to distinguish recipients vs. nonrecipients for spells like A or B. For these spells, the information on the amount of benefits received during the year in which the spell has started is used. That is, a positive amount of benefits is associated with receipt of benefits.

The need to rely on the information for the amount of benefits received during a year, in order to identify benefit receipt, creates some difficulties in the case some individuals experience two unemployment spells within a year. The reason is that it is not immediately clear whether the amount of benefits received refers to the first, to the second, or to both spells. Notice that the spells in the sample start after the first interview in 1994 (Spells A, B or C). However, an individual could be unemployed twice in the year in which the first spell starts, if another spell has started before the 1994 interview (Spell P), or if the individual re-enters unemployment after the first spell in the same year (Spells A and A1, or B and B1).

For those who experience another unemployment spell (Spell P) before entering unemployment and receive benefits during the year of entry, both sources of information 
on benefits are used to infer the benefit status. That is, if the spell is long enough so that it reaches the month of the following interview (Spell C), the dummy for receiving benefits at the time of the interview at the next wave is used. If the spell is not long enough to reach the next interview, but it reaches the following year (Spell B), then the amount of benefits received in the following year is used to infer whether the unemployed received benefits during this spell. Inference for spells of type A is not possible when another spell $\mathrm{P}$ exists and the unemployed received benefits during that year. Another type of spells for which we cannot infer the benefit status is spells followed by another spell in the same year. This is shown in Figure 1 as a combination of spells B and B1. If the individual receives benefits in both years then it is not possible to associate them with one of the two spells. Notice that in this case no spell coincides with a month in which the individual has been interviewed. The same holds for the combination of spells A and A1.

Therefore, it is possible to identify recipients and non-recipients, except for few cases in which the unemployment spell is very short and does not coincide with any month interview, or the individual experiences another spell before this spell and receives benefits in the same year. These spells are typically re-entries to unemployment after a short employment spell. Given the employment requirements for being eligible for benefits, these spells are less likely to be associated with benefits as they are preceded by a short employment spell. Therefore, they are considered as spells without benefits.

\section{B.2. Construction of Benefit Duration}

We construct a measure of benefit duration using the two available sources of information on benefits and the unemployment duration. This constructed benefit duration variable coincides with unemployment duration for those who still receive benefits at the end of unemployment spell. For instance, we consider the spell of type $\mathrm{C}$ in Figure 1. If the individual does not receive benefits at the time of the next interview, but has received benefits during the year in which entered unemployment, then it is considered as a benefit recipient who has exhausted benefits at the end of 1994 . Similarly, if an unemployed with a spell of type B receives benefits in 1994, but not in 1995, then this spell is considered as if benefits were exhausted at the end of 1994. For long spells, a comparison of benefit receipt indicator at the different waves provides information on benefit exhaustion. That is, if an unemployed receives benefits at interview in wave 2, but not at interview in wave 3 , it is assumed that has exhausted benefits at the end of 1995, given that is still unemployed. Finally, for short spells of type A, benefit duration coincides with unemployment duration. 
Figure 1

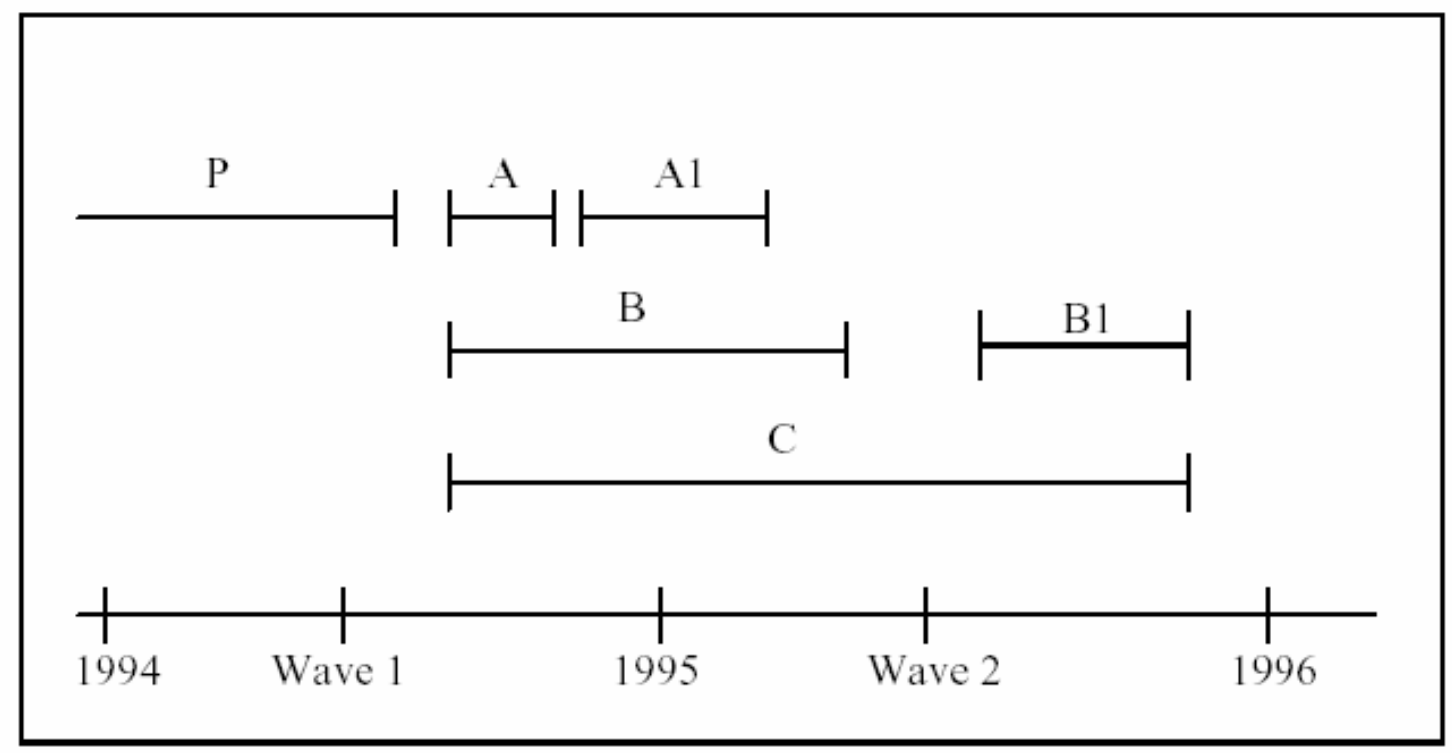




\begin{tabular}{|c|c|c|c|}
\hline & $\begin{array}{l}\text { Number of } \\
\text { Unemployment } \\
\text { Spells } \\
\end{array}$ & $\begin{array}{c}\text { Number of Spells } \\
\text { Exit to } \\
\text { Employment }\end{array}$ & $\begin{array}{l}\text { Number of Spells } \\
\text { Exit to } \\
\text { Unemployment }\end{array}$ \\
\hline Denmark & 344 & $\begin{array}{c}258 \\
(75.00)\end{array}$ & $\begin{array}{c}89 \\
(34.50)\end{array}$ \\
\hline France & 696 & $\begin{array}{c}461 \\
(66.24)\end{array}$ & $\begin{array}{c}181 \\
(39.26)\end{array}$ \\
\hline Germany & 1119 & $\begin{array}{c}709 \\
(63.36)\end{array}$ & $\begin{array}{c}303 \\
(42.74)\end{array}$ \\
\hline Greece & 948 & $\begin{array}{c}740 \\
(78.06)\end{array}$ & $\begin{array}{c}472 \\
(63.78)\end{array}$ \\
\hline Ireland & 413 & $\begin{array}{c}307 \\
(74.33)\end{array}$ & $\begin{array}{c}88 \\
(28.66)\end{array}$ \\
\hline Italy & 1276 & $\begin{array}{c}943 \\
(73.90)\end{array}$ & $\begin{array}{c}518 \\
(54.93)\end{array}$ \\
\hline Spain & 2372 & $\begin{array}{c}1822 \\
(76.81)\end{array}$ & $\begin{array}{c}1015 \\
(55.71)\end{array}$ \\
\hline UK & 507 & $\begin{array}{c}395 \\
(77.91)\end{array}$ & $\begin{array}{c}106 \\
(26.84)\end{array}$ \\
\hline
\end{tabular}

Source: ECHP (1994-2001) Own Calculations. Percentages in parentheses. 


\begin{tabular}{|c|c|c|c|c|c|c|c|c|}
\hline \multirow[b]{3}{*}{ \% Receiving Benefits } & \multicolumn{2}{|c|}{ Denmark } & \multicolumn{2}{|c|}{ France } & \multicolumn{2}{|c|}{ Germany } & \multicolumn{2}{|c|}{ Greece } \\
\hline & B & NB & B & NB & B & NB & B & NB \\
\hline & 0.686 & 0.314 & 0.590 & 0.410 & 0.658 & 0.342 & 0.266 & 0.734 \\
\hline Mean Duration & 11.42 & 6.06 & 15.35 & 8.91 & 18.23 & 7.60 & 7.95 & 8.69 \\
\hline High Educ. & 0.267 & 0.176 & 0.141 & 0.196 & 0.159 & 0.149 & 0.115 & 0.147 \\
\hline Medium Educ. & 0.458 & 0.500 & 0.484 & 0.435 & 0.559 & 0.552 & 0.387 & 0.321 \\
\hline Low Educ. & 0.275 & 0.324 & 0.375 & 0.368 & 0.282 & 0.298 & 0.498 & 0.532 \\
\hline Age & 38.55 & 35.92 & 35.51 & 33.85 & 39.39 & 36.54 & 37.31 & 35.48 \\
\hline Married & 0.466 & 0.389 & 0.433 & 0.411 & 0.632 & 0.563 & 0.628 & 0.524 \\
\hline No. of Kids & 0.636 & 0.537 & 0.886 & 0.814 & 0.763 & 0.720 & 0.775 & 0.689 \\
\hline \multirow[t]{3}{*}{ Spouse Non-Employed } & 0.246 & 0.204 & 0.299 & 0.242 & 0.332 & 0.275 & 0.415 & 0.324 \\
\hline & \multicolumn{2}{|c|}{ Ireland } & \multicolumn{2}{|c|}{ Italy } & \multicolumn{2}{|c|}{ Spain } & \multicolumn{2}{|c|}{ UK } \\
\hline & B & NB & B & $\overline{\mathrm{NB}}$ & B & NB & B & NB \\
\hline \% Receiving Benefits & 0.704 & 0.296 & 0.204 & 0.796 & 0.422 & 0.578 & 0.345 & 0.655 \\
\hline Mean Duration & 12.08 & 7.16 & 8.16 & 12.01 & 11.30 & 7.82 & 13.89 & 10.09 \\
\hline High Educ. & 0.058 & 0.115 & 0.042 & 0.038 & 0.098 & 0.116 & 0.371 & 0.346 \\
\hline Medium Educ. & 0.357 & 0.352 & 0.272 & 0.299 & 0.151 & 0.208 & 0.137 & 0.169 \\
\hline Low Educ. & 0.584 & 0.533 & 0.686 & 0.663 & 0.752 & 0.676 & 0.491 & 0.485 \\
\hline Age & 35.97 & 36.43 & 39.16 & 33.52 & 37.52 & 32.76 & 36.41 & 35.11 \\
\hline Married & 0.522 & 0.467 & 0.686 & 0.408 & 0.662 & 0.393 & 0.469 & 0.463 \\
\hline No. of Kids & 1.268 & 1.057 & 0.908 & 0.555 & 0.900 & 0.661 & 0.931 & 0.894 \\
\hline Spouse Non-Employed & 0.402 & 0.262 & 0.345 & 0.269 & 0.491 & 0.281 & 0.314 & 0.234 \\
\hline
\end{tabular}

Source: ECHP(1994-2001) Own calculations. B denotes benefit recipient and NB non-recipient. 


\begin{tabular}{|c|c|c|c|c|c|c|c|c|}
\hline \multirow[b]{3}{*}{ Months } & & & \multicolumn{4}{|c|}{ UNEMPLOYMENT SPELLS } & & \\
\hline & \multicolumn{2}{|c|}{ Denmark } & \multicolumn{2}{|c|}{ France } & \multicolumn{2}{|c|}{ Germany } & \multicolumn{2}{|c|}{ Greece } \\
\hline & $\mathrm{B}$ & $\mathrm{NB}$ & B & NB & B & NB & $\bar{B}$ & NB \\
\hline 1 & 0.970 & 0.972 & 0.978 & 0.944 & 0.982 & 0.935 & 0.964 & 0.968 \\
\hline 6 & 0.466 & 0.300 & 0.648 & 0.516 & 0.667 & 0.432 & 0.327 & 0.426 \\
\hline \multirow[t]{2}{*}{12} & 0.303 & 0.199 & 0.484 & 0.362 & 0.498 & 0.282 & 0.201 & 0.227 \\
\hline & \multicolumn{2}{|c|}{ Ireland } & \multicolumn{2}{|c|}{ Italy } & \multicolumn{2}{|c|}{ Spain } & \multicolumn{2}{|c|}{ UK } \\
\hline Months & B & NB & $\bar{B}$ & NB & $\bar{B}$ & NB & B & NB \\
\hline 1 & 0.969 & 0.943 & 0.973 & 0.967 & 0.973 & 0.944 & 0.971 & 0.949 \\
\hline 6 & 0.635 & 0.345 & 0.397 & 0.553 & 0.529 & 0.944 & 0.635 & 0.380 \\
\hline \multirow[t]{3}{*}{12} & 0.360 & 0.200 & 0.206 & 0.352 & 0.307 & 0.223 & 0.435 & 0.265 \\
\hline & & & \multicolumn{4}{|c|}{ EMPLOYMENT SPELLS } & & \\
\hline & \multicolumn{2}{|c|}{ Denmark } & \multicolumn{2}{|c|}{ France } & \multicolumn{2}{|c|}{ Germany } & \multicolumn{2}{|c|}{ Greece } \\
\hline Months & B & NB & B & NB & $\bar{B}$ & NB & $\bar{B}$ & NB \\
\hline 1 & 0.994 & 0.974 & 0.989 & 0.985 & 0.996 & 0.983 & 0.990 & 0.993 \\
\hline 6 & 0.879 & 0.865 & 0.845 & 0.747 & 0.909 & 0.843 & 0.675 & 0.993 \\
\hline \multirow[t]{2}{*}{12} & 0.879 & 0.771 & 0.727 & 0.592 & 0.719 & 0.674 & 0.273 & 0.488 \\
\hline & \multicolumn{2}{|c|}{ Ireland } & \multicolumn{2}{|c|}{ Italy } & \multicolumn{2}{|c|}{ Spain } & \multicolumn{2}{|c|}{ UK } \\
\hline Months & B & NB & B & NB & B & NB & B & NB \\
\hline 1 & 0.969 & 0.969 & 0.986 & 0.989 & 0.985 & 0.980 & 0.992 & 0.985 \\
\hline 6 & 0.875 & 0.969 & 0.711 & 0.752 & 0.672 & 0.719 & 0.883 & 0.894 \\
\hline 12 & 0.793 & 0.969 & 0.336 & 0.542 & 0.483 & 0.540 & 0.822 & 0.823 \\
\hline
\end{tabular}

Notes: ECHP(1994-2001) Own calculations. B denotes benefit recipient and NB non-recipient. Survival functions based on Kaplan-Meier estimates show the share of spells survived after 1, 6 and 12 months in unemployment and employment, respectively. 


\begin{tabular}{|c|c|c|c|c|c|c|c|c|}
\hline \multirow[b]{3}{*}{ Unemployment } & \multicolumn{2}{|c|}{ Denmark } & \multicolumn{2}{|c|}{ France } & \multicolumn{2}{|c|}{ Germany } & \multicolumn{2}{|c|}{ Greece } \\
\hline & Coef. & s.e. & Coef. & s.e. & Coef. & s.e. & Coef. & s.e. \\
\hline & & & & & & & & \\
\hline Receiving Benefits & -0.486 & $0.257 *$ & -0.422 & $0.144 * * *$ & -0.825 & $0.153 * * *$ & -0.274 & $0.135 * *$ \\
\hline High Educ. & -0.211 & 0.189 & 0.120 & 0.159 & 0.488 & $0.158 * * *$ & -0.019 & 0.120 \\
\hline Secondary Educ. & -0.019 & 0.161 & 0.383 & $0.110 * * *$ & 0.361 & $0.115 * * *$ & -0.086 & 0.091 \\
\hline Age $20-24$ & 0.233 & 0.301 & 1.986 & $0.265 * * *$ & 1.270 & $0.205 * * *$ & 0.302 & 0.185 \\
\hline Age 25-29 & 0.760 & $0.262 * * *$ & 2.002 & $0.249 * * *$ & 1.423 & $0.184 * * *$ & 0.475 & $0.163 * * *$ \\
\hline Age 30-39 & 0.883 & $0.226 * * *$ & 1.701 & $0.241 * * *$ & 1.369 & $0.161 * * *$ & 0.566 & $0.153 * * *$ \\
\hline Age 40-49 & 0.715 & $0.250 * * *$ & 1.500 & $0.240 * * *$ & 1.102 & $0.160 * * *$ & 0.280 & $0.143 *$ \\
\hline Married & 0.048 & 0.176 & 0.167 & 0.135 & 0.264 & $0.116 * *$ & 0.253 & $0.143 *$ \\
\hline Number of Kids & 0.054 & 0.083 & 0.049 & 0.052 & 0.034 & 0.051 & 0.090 & 0.056 \\
\hline Spouse Non-Emp. & -0.387 & $0.168 * *$ & 0.142 & 0.124 & -0.164 & 0.110 & 0.114 & 0.109 \\
\hline Regional Un. Rate & 0.069 & 0.059 & 0.004 & 0.018 & 0.020 & 0.012 & 0.008 & 0.021 \\
\hline \multicolumn{9}{|l|}{ Employment } \\
\hline Received Benefits & -1.133 & $0.333 * * *$ & -1.416 & $0.183 * * *$ & -1.606 & $0.201 * * *$ & -0.191 & 0.142 \\
\hline Un. Dur. (1-6 M) & 0.726 & 0.447 & -0.113 & 0.221 & -0.199 & 0.214 & 0.276 & 0.191 \\
\hline Un. Dur. (7-12 M) & 0.887 & $0.490 *$ & -0.279 & 0.263 & -0.127 & 0.244 & -0.022 & 0.220 \\
\hline High Educ. & -0.198 & 0.329 & -0.382 & 0.295 & -0.658 & $0.258 * *$ & -0.332 & $0.162 * *$ \\
\hline Secondary Educ. & -0.187 & 0.262 & -0.199 & 0.168 & -0.405 & $0.189 * *$ & -0.127 & 0.113 \\
\hline Age $20-24$ & -0.077 & 0.540 & 1.206 & $0.488 * * *$ & -0.503 & 0.317 & 0.310 & 0.233 \\
\hline Age 25-29 & -0.316 & 0.411 & 0.753 & 0.476 & -0.144 & 0.264 & 0.107 & 0.199 \\
\hline Age 30-39 & -0.715 & $0.373 *$ & 0.650 & 0.469 & -0.429 & $0.232 *$ & 0.167 & 0.183 \\
\hline Age $40-49$ & -0.749 & $0.414 *$ & 0.599 & 0.475 & -0.352 & 0.237 & 0.275 & 0.169 \\
\hline Married & -0.310 & 0.312 & -0.298 & 0.208 & -0.264 & 0.184 & -0.036 & 0.172 \\
\hline Number of Kids & -0.024 & 0.149 & 0.030 & 0.091 & 0.029 & 0.085 & -0.032 & 0.067 \\
\hline Spouse Non-Emp. & 0.127 & 0.296 & 0.078 & 0.219 & 0.311 & $0.174 *$ & 0.239 & $0.134 *$ \\
\hline Part-Time Job & -0.763 & 0.618 & 0.416 & $0.227 *$ & 0.357 & 0.297 & 0.142 & 0.139 \\
\hline Regional Un. Rate & 0.098 & 0.114 & 0.033 & 0.028 & 0.051 & $0.020 * *$ & -0.010 & 0.031 \\
\hline Log-Likelihood & \multicolumn{2}{|c|}{-1305.02} & \multicolumn{2}{|c|}{-1293.51} & \multicolumn{2}{|c|}{-892.00} & \multicolumn{2}{|c|}{-1391.79} \\
\hline
\end{tabular}

Notes: $* * *, * *$, and $*$ denote significance at the $1 \%, 5 \%$, and $10 \%$ level, respectively. The unemployment and employment hazard functions are estimated for each country jointly with the benefit equation allowing for correlated discrete unobserved heterogeneity. Each hazard function includes year dummies for the year entering in unemployment and employment, respectively. 
$\overline{\text { Table 4b. Unemployment and Employment Hazard Estimates with Unobserved Heterogeneity (cont.) }}$

\begin{tabular}{|c|c|c|c|c|c|c|c|c|}
\hline \multirow{3}{*}{ Unemployment } & \multicolumn{2}{|c|}{ Ireland } & \multicolumn{2}{|c|}{$\overline{\text { Italy }}$} & \multicolumn{2}{|c|}{ Spain } & \multicolumn{2}{|c|}{$\overline{\mathrm{UK}}$} \\
\hline & Coef. & $\overline{\text { s.e. }}$ & Coef. & s.e. & Coef. & s.e. & Coef. & s.e. \\
\hline & & & & & & & & \\
\hline Receiving Benefits & 0.090 & 0.261 & -0.331 & $0.130 * *$ & -0.412 & $0.075 * * *$ & -0.721 & $0.233 * * *$ \\
\hline High Educ. & 0.216 & 0.245 & 0.466 & $0.189 * *$ & 0.074 & 0.085 & 0.304 & $0.122 * *$ \\
\hline Secondary Educ. & 0.300 & $0.133 * *$ & 0.202 & $0.080 * *$ & -0.052 & 0.067 & 0.050 & 0.159 \\
\hline Age $20-24$ & 0.554 & $0.254 * *$ & 0.405 & $0.170 * *$ & 0.800 & $0.111 * * *$ & 0.646 & $0.214 * * *$ \\
\hline Age 25-29 & 0.594 & $0.258 * *$ & 0.371 & $0.157 * *$ & 0.789 & $0.106 * * *$ & 0.554 & $0.211 * *$ \\
\hline Age 30-39 & 0.433 & $0.209 * *$ & 0.377 & $0.134 * * *$ & 0.707 & $0.095 * * *$ & 0.346 & $0.204 *$ \\
\hline Age 40-49 & 0.304 & 0.201 & 0.319 & $0.137 * *$ & 0.573 & $0.099 * * *$ & 0.211 & 0.194 \\
\hline Married & 0.357 & $0.215 *$ & 0.454 & $0.129 * * *$ & 0.172 & $0.082 * *$ & 0.184 & 0.143 \\
\hline Number of Kids & 0.008 & 0.054 & 0.047 & 0.045 & -0.012 & 0.028 & -0.072 & 0.055 \\
\hline Spouse Non-Emp. & -0.167 & 0.181 & -0.069 & 0.100 & 0.118 & 0.075 & -0.357 & $0.141 * *$ \\
\hline Regional Un. Rate & 0.030 & 0.052 & -0.018 & $0.004 * * *$ & 0.003 & 0.004 & -0.027 & 0.022 \\
\hline \multicolumn{9}{|l|}{ Employment } \\
\hline Received Benefits & -0.243 & 0.432 & -0.381 & $0.147 * * *$ & -0.516 & $0.088 * * *$ & -2.130 & $0.361 * * *$ \\
\hline Un. Dur. (1-6 M) & 0.071 & 0.338 & 0.359 & $0.155 * * *$ & 0.288 & $0.108 * * *$ & -0.365 & 0.278 \\
\hline Un. Dur. (7-12 M) & 0.538 & 0.344 & 0.405 & $0.170 * * *$ & 0.364 & $0.118 * * *$ & -0.547 & 0.373 \\
\hline High Educ. & 0.169 & 0.465 & -0.109 & 0.247 & -0.236 & $0.120 *$ & -0.620 & $0.245 * *$ \\
\hline Secondary Educ. & -0.268 & 0.246 & -0.068 & 0.109 & -0.121 & 0.091 & -0.527 & $0.298 *$ \\
\hline Age $20-24$ & -0.260 & 0.486 & -0.566 & $0.240 * *$ & -0.436 & $0.145 * * *$ & -0.078 & 0.399 \\
\hline Age 25-29 & -0.178 & 0.467 & -0.367 & $0.210 *$ & -0.404 & $0.135 * * *$ & 0.425 & 0.386 \\
\hline Age 30-39 & 0.062 & 0.356 & -0.193 & 0.168 & -0.445 & $0.120 * * *$ & -0.255 & 0.396 \\
\hline Age 40-49 & 0.306 & 0.337 & -0.212 & 0.169 & -0.196 & 0.121 & -0.334 & 0.397 \\
\hline Married & -0.112 & 0.334 & -0.162 & 0.174 & -0.398 & $0.113 * * *$ & -0.861 & $0.279 * * *$ \\
\hline Number of Kids & 0.115 & 0.099 & -0.012 & 0.064 & 0.069 & $0.040 *$ & 0.106 & 0.110 \\
\hline Spouse Non-Emp. & -0.337 & 0.301 & -0.142 & 0.130 & 0.055 & 0.100 & 0.242 & 0.269 \\
\hline Part-Time Job & 0.792 & $0.250 * * *$ & 0.101 & 0.144 & 0.532 & $0.113 * * *$ & 0.203 & 0.278 \\
\hline Regional Un. Rate & 0.019 & 0.079 & 0.029 & $0.005 * *$ & 0.039 & $0.006 * * *$ & 0.014 & 0.040 \\
\hline Log-Likelihood & \multicolumn{2}{|c|}{-1178.24} & \multicolumn{2}{|c|}{-1317.83} & \multicolumn{2}{|c|}{-1328.68} & \multicolumn{2}{|c|}{-1429.03} \\
\hline
\end{tabular}

Notes: $* * *, * *$,and $*$ denote significance at the $1 \%, 5 \%$, and $10 \%$ level, respectively. The unemployment and employment hazard functions are estimated for each country jointly with the benefit equation allowing for correlated discrete unobserved heterogeneity. Each hazard function includes year dummies for the year entering in unemployment and employment, respectively. 
Table 5. Heterogeneity Estimates of Benefits by Education.

\section{Unemployment}

Reveiving Benefits (RB)

$\mathrm{RB} *$ High Education

$\mathrm{RB} *$ Medium Education

\section{Unemployment}

Reveiving Benefits (RB)

$\mathrm{RB} *$ High Education

$\mathrm{RB} *$ Medium Education

\section{Employment}

Reveiving Benefits (RB)

$\mathrm{RB} *$ High Education

$\mathrm{RB} *$ Medium Education

Log-Likelihood

\section{Employment}

Reveiving Benefits (RB)

$\mathrm{RB} *$ High Education

$\mathrm{RB} *$ Medium Education

Log-Likelihood

\begin{tabular}{rr}
\hline \multicolumn{2}{c}{ Denmark } \\
\hline Coef. & s.e. \\
-0.450 & 0.358 \\
-0.399 & 0.419 \\
0.032 & 0.346
\end{tabular}

\begin{tabular}{rr}
\hline \multicolumn{2}{c}{ Ireland } \\
\hline Coef. & s.e. \\
0.068 & 0.287 \\
0.178 & 0.487 \\
0.029 & 0.284
\end{tabular}

\begin{tabular}{rr}
\hline \multicolumn{2}{c}{ Denmark } \\
\hline Coef. & s.e. \\
-0.594 & 0.519
\end{tabular}

-2.0850 .824 **

$\begin{array}{ll}-0.634 & 0.668\end{array}$

$-1305.01$

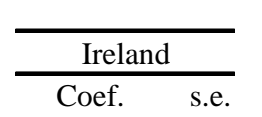

$\begin{array}{ll}-0.301 & 0.465\end{array}$

$1.645 \quad 1.199$

0.0550 .556

\begin{tabular}{rc}
\hline \multicolumn{2}{c}{ France } \\
\hline Coef. & s.e. \\
-0.347 & 0.197
\end{tabular} *

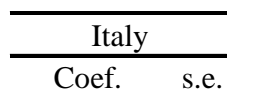

$\frac{\text { Spain }}{\text { Coef. }}$

$-0.3830 .143 * * *$

$\begin{array}{ll}0.095 & 0.445\end{array}$

0.1750 .192

$\begin{array}{ll}-0.446 & 0.080 * * *\end{array}$

$\begin{array}{ll}-0.027 & 0.167\end{array}$

0.2270 .134 *

Notes: $* * *, * *$,and $*$ denote significance at the $1 \%, 5 \%$, and $10 \%$ level, respectively. The unemployment and employment hazard functions are estimated for each country jointly with the benefit equation allowing for correlated discrete unobserved heterogeneity. Each hazard function includes year dummies for the year entering in unemployment and employment, respectively. Other coefficients are similar as in Table 4a and 4b and are not reported. 
Table 6. Heterogeneity Estimates of Benefits by Previous Unemployment Duration.

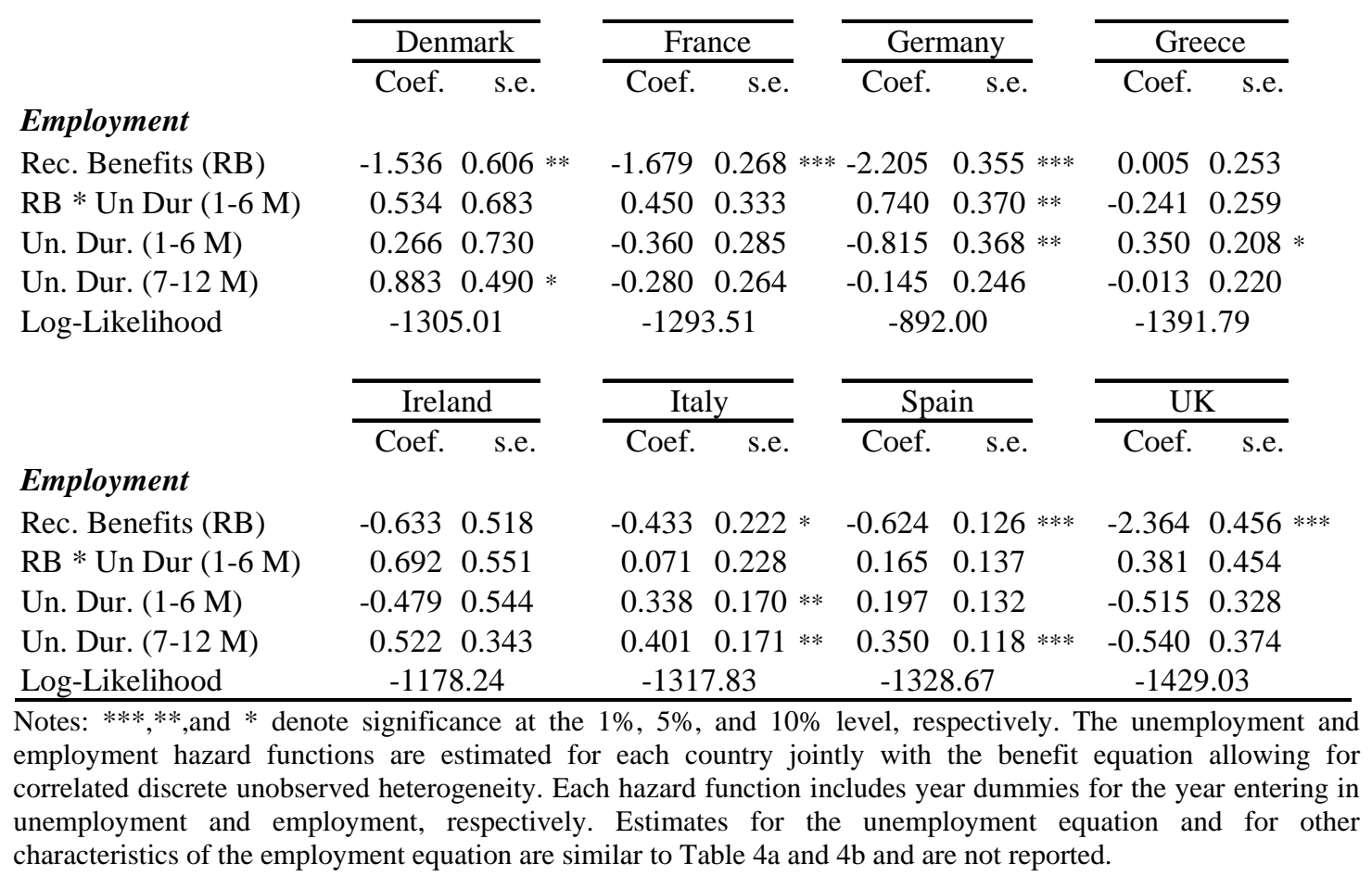


Table 7. Duration Dependence and Unobserved Heterogeneity Distibution Estimates

\begin{tabular}{|c|c|c|c|c|c|c|c|c|c|c|c|c|}
\hline & \multirow{2}{*}{\multicolumn{2}{|c|}{ Denmark }} & & \multirow{2}{*}{\multicolumn{2}{|c|}{ France }} & & \multirow{2}{*}{\multicolumn{2}{|c|}{ Germany }} & & \multirow{2}{*}{\multicolumn{2}{|c|}{ Greece }} & \\
\hline & & & & & & & & & & & & \\
\hline & Coef. & $\overline{\text { s.e. }}$ & & Coef. & $\overline{\text { s.e. }}$ & & Coef. & $\overline{\text { s.e. }}$ & & Coef. & $\overline{\text { s.e. }}$ & \\
\hline \multicolumn{13}{|l|}{ Unemployment } \\
\hline Duration 6-12 M & -0.556 & 0.188 & $* * *$ & -0.378 & 0.128 & $* * *$ & -0.311 & 0.114 & $* * *$ & -0.311 & 0.102 & $* * *$ \\
\hline Duration $12-24 \mathrm{M}$ & -1.023 & 0.233 & $* * *$ & -0.493 & 0.133 & $* * *$ & -0.967 & 0.141 & $* * *$ & -1.253 & 0.158 & $* * *$ \\
\hline Duration 24+ M & -2.135 & 0.362 & $* * *$ & -1.354 & 0.203 & $* * *$ & -2.216 & 0.238 & $* * *$ & -2.155 & 0.245 & $* * *$ \\
\hline \multicolumn{13}{|l|}{ Employment } \\
\hline Duration 6-12 M & 0.367 & 0.262 & & -0.093 & 0.183 & & 0.926 & 0.171 & $* * *$ & 0.922 & 0.107 & $* * *$ \\
\hline Duration $12-24 \mathrm{M}$ & -0.428 & 0.313 & & -0.897 & 0.232 & $* * *$ & 0.138 & 0.203 & & -0.808 & 0.173 & $* * *$ \\
\hline Duration 24+ M & -1.443 & 0.377 & $* * *$ & -1.541 & 0.279 & $* * *$ & -0.488 & 0.255 & $*$ & -1.521 & 0.207 & $* * *$ \\
\hline \multicolumn{13}{|c|}{ Unobs. Heterogeneity } \\
\hline MPoint1 Unem & -3.086 & 0.745 & $* * *$ & -4.314 & 0.369 & $* * *$ & -4.092 & 0.265 & $* * *$ & -2.740 & 0.329 & $* * *$ \\
\hline MPoint2 Unem & 0.109 & 0.305 & & 0.120 & 0.170 & & 0.236 & 0.178 & & 0.419 & 0.125 & $* * *$ \\
\hline MPoint1 Empl. & -6.487 & 1.445 & $* * *$ & -5.017 & 0.658 & $* * *$ & -5.108 & 0.523 & $* * *$ & -3.906 & 0.482 & $* * *$ \\
\hline MPoint2 Empl. & 2.672 & 0.537 & $* * *$ & 1.821 & 0.251 & $* * *$ & 2.505 & 0.275 & $* * *$ & 1.032 & 0.138 & $* * *$ \\
\hline MPoint1 Benefits & -inf & & & -inf & & & -inf & & & -2.155 & 0.245 & $* * *$ \\
\hline MPoint2 Benefits & -2.135 & 0.362 & $* * *$ & -1.354 & 0.203 & $* * *$ & -2.216 & 0.238 & $* * *$ & 7.633 & 0.640 & $* * *$ \\
\hline \multirow[t]{3}{*}{ Probability } & 0.284 & 0.143 & $* * *$ & 0.327 & 0.097 & $* * *$ & 0.321 & 0.085 & $* * *$ & 0.704 & 0.097 & $* * *$ \\
\hline & \multicolumn{2}{|c|}{ Ireland } & & \multicolumn{2}{|c|}{ Italy } & & \multicolumn{2}{|c|}{ Spain } & & \multicolumn{2}{|c|}{ UK } & \\
\hline & Coef. & $\overline{\text { s.e. }}$ & & Coef. & $\overline{\text { s.e. }}$ & & Coef. & $\overline{\text { s.e. }}$ & & Coef. & $\overline{\text { s.e. }}$ & \\
\hline \multicolumn{13}{|l|}{ Unemployment } \\
\hline Duration 6-12 M & 0.093 & 0.146 & & -0.162 & 0.084 & $*$ & -0.142 & 0.061 & $* *$ & -0.600 & 0.148 & $* * *$ \\
\hline Duration $12-24 \mathrm{M}$ & -0.578 & 0.190 & $* * *$ & -1.013 & 0.118 & $* * *$ & -0.867 & 0.085 & $* * *$ & -0.710 & 0.158 & $* * *$ \\
\hline Duration 24+ M & -1.222 & 0.287 & $* * *$ & -1.598 & 0.154 & $* * *$ & -1.541 & 0.123 & $* * *$ & -2.127 & 0.245 & $* * *$ \\
\hline \multicolumn{13}{|l|}{ Employment } \\
\hline Duration 6-12 M & -0.220 & 0.282 & & 0.533 & 0.099 & $* * *$ & -0.040 & 0.076 & & -0.180 & 0.270 & \\
\hline Duration 12-24 M & -0.767 & 0.303 & $* *$ & -1.305 & 0.175 & $* * *$ & -1.176 & 0.107 & $* * *$ & -0.484 & 0.276 & $*$ \\
\hline Duration 24+ M & -0.960 & 0.316 & $* * *$ & -1.911 & 0.205 & $* * *$ & -1.559 & 0.124 & $* * *$ & -1.151 & 0.306 & $* * *$ \\
\hline \multicolumn{13}{|c|}{ Unobs. Heterogeneity } \\
\hline MPoint1 Unem & -2.924 & 0.758 & $* * *$ & -2.804 & 0.187 & $* * *$ & -3.053 & 0.139 & $* * *$ & -2.319 & 0.274 & $* * *$ \\
\hline MPoint2 Unem & -0.841 & 0.286 & $* * *$ & 0.791 & 0.115 & $* * *$ & 0.286 & 0.079 & $* * *$ & 0.304 & 0.227 & \\
\hline MPoint1 Empl. & -4.864 & 1.092 & $* * *$ & -3.689 & 0.302 & $* * *$ & -3.853 & 0.214 & $* * *$ & -3.998 & 0.659 & $* * *$ \\
\hline MPoint2 Empl. & 0.527 & 0.467 & & 0.990 & 0.137 & $* * *$ & 1.022 & 0.099 & $* * *$ & 2.495 & 0.346 & $* * *$ \\
\hline MPoint1 Benefits & -1.222 & 0.287 & $* * *$ & -inf & & & -7.583 & 1.944 & $* * *$ & -inf & & \\
\hline MPoint2 Benefits & 7.517 & 0.562 & $* * *$ & 0.609 & 0.544 & & 8.967 & 1.875 & & 3.502 & 1.007 & $* * *$ \\
\hline Probability & 0.299 & 0.124 & $* * *$ & 0.805 & 0.093 & $* * *$ & 0.502 & 0.057 & $* * *$ & 0.625 & 0.099 & $* * *$ \\
\hline
\end{tabular}

Notes: Reference category for duration dependence is duration less than 6 months both for unemployment and employment. ***,**, and * denote significance at the $1 \%, 5 \%$, and $10 \%$ level, respectively. For the discrete unobserved heterogeneity we allow for two mass points in each process normalizing one to zero since we include a constant in the vector of covariates. The second mass point can be interpreted as the deviation from the first. We also report the mass point estimates from the auxiliary benefit equation. We assume there is perfect correlation between the two points of support with a mixing distribution that has a logit specification. 


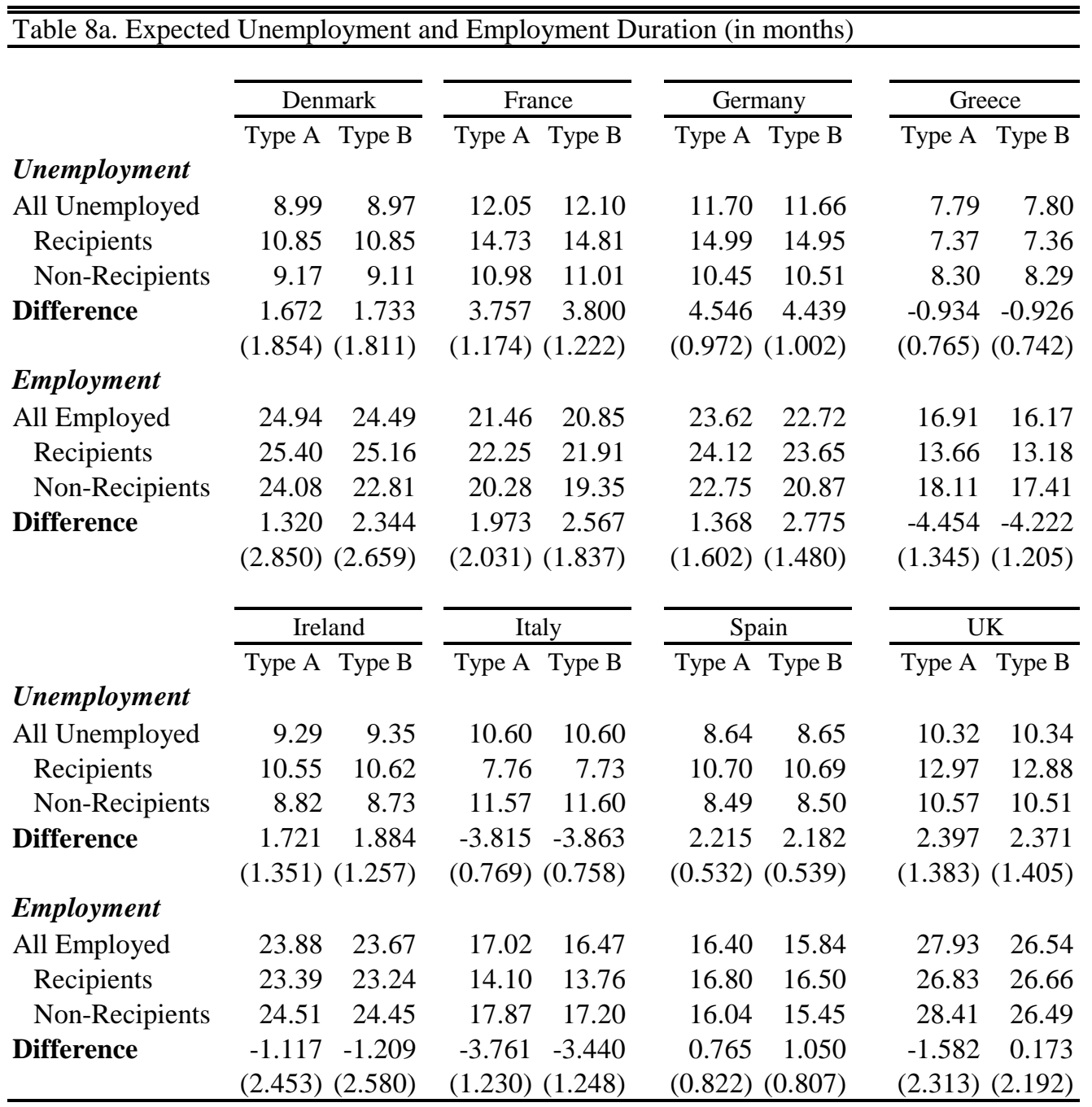

Note: Expected durations based on estimated coefficients from the multi-state duration model. Type $\mathrm{A}$ and B correspond to the two mass points of the discrete unobserved heterogeneity distribution which was estimated. Differences refer to differences in expected duration between recipients and non-recipients. Standard deviations in parentheses are obtained by the bootstrap method. 


\begin{tabular}{|c|c|c|c|c|c|c|c|c|}
\hline \multirow{2}{*}{ Employed by Previo } & \multicolumn{2}{|c|}{ Denmark } & \multicolumn{2}{|c|}{ France } & \multicolumn{2}{|c|}{ Germany } & \multicolumn{2}{|c|}{ Greece } \\
\hline & Type A & Type B & Type A & Type B & Type A & Type B & Type A & Type B \\
\hline \multicolumn{9}{|c|}{ Unemployment Duration } \\
\hline \multicolumn{9}{|l|}{ All Employed } \\
\hline UD 1-6 Months & 25.19 & 25.29 & 22.64 & 22.73 & 25.19 & 25.21 & 16.67 & 16.74 \\
\hline UD 6+ Months & 23.89 & 23.78 & 19.78 & 19.70 & 21.10 & 21.15 & 17.31 & 17.17 \\
\hline $\begin{array}{l}\text { Recipients } \\
\text { UD 1-6 Months }\end{array}$ & 24.59 & 24.62 & 23.60 & 23.68 & 26.14 & 26.22 & 13.79 & 13.72 \\
\hline $\begin{array}{l}\text { Non-Recipients } \\
\text { UD 1-6 Months }\end{array}$ & 26.25 & 26.07 & 21.36 & 21.45 & 23.89 & 23.77 & 17.87 & 17.92 \\
\hline Difference & $\begin{array}{r}-1.658 \\
(3.366)\end{array}$ & $\begin{array}{r}-1.454 \\
(3.279)\end{array}$ & $\begin{array}{r}2.245 \\
(2.681)\end{array}$ & $\begin{array}{r}2.235 \\
(2.706)\end{array}$ & $\begin{array}{r}2.252 \\
(1.997)\end{array}$ & $\begin{array}{r}2.450 \\
(1.826)\end{array}$ & $\begin{array}{c}-4.081 \\
(1.493)\end{array}$ & $\begin{array}{r}-4.206 \\
(1.545)\end{array}$ \\
\hline $\begin{array}{l}\text { Recipients } \\
\text { UD 6+ Months }\end{array}$ & 26.90 & 26.60 & 20.39 & 20.34 & 21.78 & 21.66 & 12.87 & 12.86 \\
\hline $\begin{array}{l}\text { Non-Recipients } \\
\text { UD 6+ Months }\end{array}$ & 9.75 & 9.76 & 18.28 & 18.34 & 17.63 & 17.34 & 18.39 & 18.40 \\
\hline Difference & $\begin{array}{l}17.148 \\
(3.606)\end{array}$ & $\begin{array}{r}16.831 \\
(3.671)\end{array}$ & $\begin{array}{r}2.108 \\
(2.814)\end{array}$ & $\begin{array}{r}1.997 \\
(2.852)\end{array}$ & $\begin{array}{r}4.152 \\
(2.673)\end{array}$ & $\begin{array}{r}4.318 \\
(2.691)\end{array}$ & $\begin{array}{c}-5.512 \\
(2.430)\end{array}$ & $\begin{array}{r}-5.537 \\
(2.509)\end{array}$ \\
\hline & Irel & and & Ita & ly & Spa & ain & $\overline{\mathrm{UK}}$ & $\mathrm{K}$ \\
\hline \multicolumn{8}{|c|}{ Employed by Previous } & Type B \\
\hline \multicolumn{9}{|c|}{$\begin{array}{l}\text { Unemployment Duration } \\
\text { All Employed }\end{array}$} \\
\hline UD 1-6 Months & 25.53 & 25.52 & 17.14 & 17.16 & 16.71 & 16.73 & 28.79 & 28.82 \\
\hline UD 6+ Months & 21.61 & 21.61 & 16.84 & 16.76 & 15.74 & 15.83 & 26.22 & 26.25 \\
\hline $\begin{array}{l}\text { Recipients } \\
\text { UD 1-6 Months }\end{array}$ & 24.38 & 24.49 & 13.28 & 13.30 & 16.60 & 16.70 & 26.90 & 26.69 \\
\hline $\begin{array}{l}\text { Non-Recipients } \\
\text { UD 1-6 Months }\end{array}$ & 26.70 & 26.93 & 18.38 & 18.42 & 16.75 & 16.73 & 29.22 & 29.17 \\
\hline Difference & $\begin{array}{r}-2.324 \\
(3.109)\end{array}$ & $\begin{array}{r}-2.444 \\
(3.288)\end{array}$ & $\begin{array}{r}-5.093 \\
(1.408)\end{array}$ & $\begin{array}{r}-5.122 \\
(1.460)\end{array}$ & $\begin{array}{r}-0.148 \\
(1.017)\end{array}$ & $\begin{array}{r}-0.032 \\
(1.054)\end{array}$ & $\begin{array}{c}-2.323 \\
(3.316)\end{array}$ & $\begin{array}{r}-2.472 \\
(3.614)\end{array}$ \\
\hline $\begin{array}{l}\text { Recipients } \\
\text { UD 6+ Months }\end{array}$ & 22.35 & 22.29 & 15.57 & 15.43 & 17.12 & 17.19 & 26.48 & 26.48 \\
\hline $\begin{array}{l}\text { Non-Recipients } \\
\text { UD 6+ Months }\end{array}$ & 17.10 & 16.86 & 17.01 & 17.04 & 14.52 & 14.46 & 25.42 & 25.42 \\
\hline Difference & $\begin{array}{r}5.250 \\
(3.527)\end{array}$ & $\begin{array}{r}5.428 \\
(3.676)\end{array}$ & $\begin{array}{r}-1.437 \\
(2.252)\end{array}$ & $\begin{array}{r}-1.609 \\
(2.156)\end{array}$ & $\begin{array}{r}2.595 \\
(1.206)\end{array}$ & $\begin{array}{r}2.723 \\
(1.179)\end{array}$ & $\begin{array}{r}1.055 \\
(3.413)(\end{array}$ & $\begin{array}{r}1.057 \\
(3.211)\end{array}$ \\
\hline
\end{tabular}

Note: Expected durations based on estimated coefficients from the multi-state duration model. Type A and B correspond to the two mass points of the discrete unobserved heterogeneity distribution which was estimated. UD denotes Unemployment Duration distinguishing between 1-6 and 6+ months. Differences refer to differences in expected duration between recipients and non-recipients. Standard deviations in parentheses are obtained by the bootstrap method. 


\begin{tabular}{|c|c|c|c|c|}
\hline & Schemes & Employment/contributions conditions & Payment rate & Duration (months) \\
\hline Denmark & Insurance & 52 weeks in 3 years & $90 \%$ of reference earnings & $1+3$ years \\
\hline France & Insurance & 4 months in last 18 months & $\begin{array}{l}40 \% \text { to } 57 \% \text { decreasing at } 4 \\
\text { monthly intervals }\end{array}$ & 4-60 months depending on age \\
\hline Germany & $\begin{array}{l}\text { Insurance } \\
\text { Assistance }\end{array}$ & $\begin{array}{l}12 \text { months in } 3 \text { years } \\
\text { Received UI during last year or being in need }\end{array}$ & $\begin{array}{l}60 \% \text { of net earnings for singles and } 67 \% \text { with children } \\
53 \% \text { of net earnings for single and } 57 \% \text { with children }\end{array}$ & $\begin{array}{l}\text { 12-64 months depending on age and contribution history } \\
\text { Unlimited - renewable every year }\end{array}$ \\
\hline Greece & Insurance & $\begin{array}{l}125 \text { days during } 14 \text { months, } \\
\text { or } 200 \text { days during } 2 \text { years }\end{array}$ & $40 \%$ of daily wage for manual and $50 \%$ for white collar & 5-12 months depending on contribution history \\
\hline Ireland & $\begin{array}{l}\text { Insurance } \\
\text { Assistance }\end{array}$ & $\begin{array}{l}39 \text { weeks in } 1 \text { year } \\
\text { Means tested }\end{array}$ & $\begin{array}{l}\text { Flat rate (98 Euros per week) } \\
\text { Flat rate (97-98 Euros per week) }\end{array}$ & $\begin{array}{l}390 \text { days } \\
\text { Unlimited }\end{array}$ \\
\hline Italy & $\begin{array}{l}\text { Ordinary } \\
\text { Special } \\
\text { Mobility }\end{array}$ & $\begin{array}{c}52 \text { weeks in } 2 \text { years } \\
43 \text { weeks in } 2 \text { years in building industry } \\
12 \text { months with at least } 6 \text { months } \\
\text { of effective work in a firm }\end{array}$ & $\begin{array}{c}30 \% \text { of average wage in last } 3 \text { months } \\
80 \% \text { of earnings } \\
80 \% \text { of earnings supplement }\end{array}$ & $\begin{array}{l}180 \text { days } \\
90 \text { days } \\
36 \text { months }\end{array}$ \\
\hline Spain & Insurance & 12 months in 6 years & $70 \%$ of earnings in first 180 days and $60 \%$ afterwards & 4-24 months depending on contribution history \\
\hline UK & Insurance & $\begin{array}{c}\text { Contributions paid in one of the } 2 \text { tax years } \\
\text { on which the claim is based amounting to at least } \\
25 \text { times the minimun contribution for that year } \\
\text { Means Tested }\end{array}$ & Flat rate (65-83 Euros per week) depending on age & 182 days \\
\hline
\end{tabular}




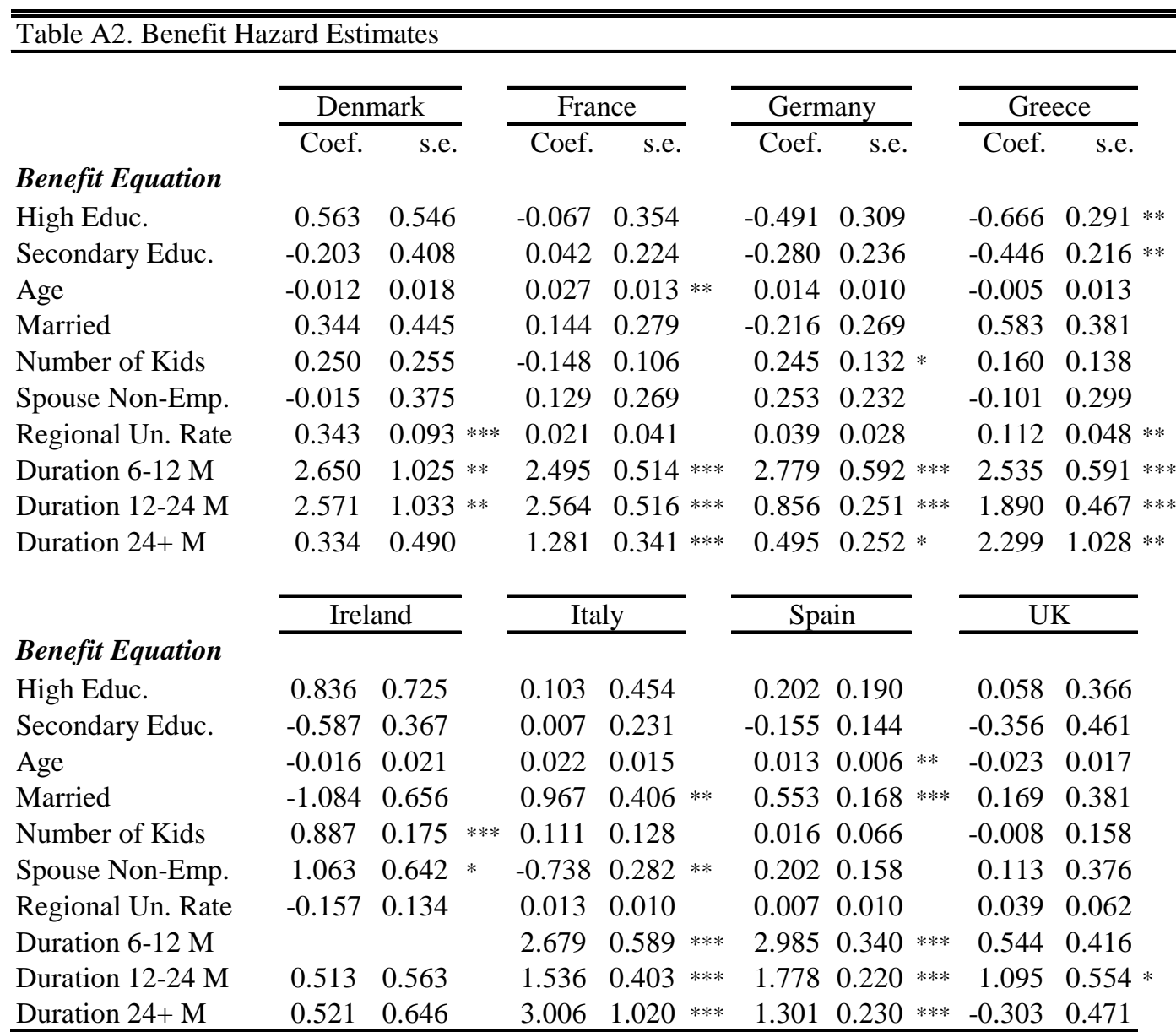

Notes: $* * *, * *$,and $*$ denote significance at the $1 \%, 5 \%$, and $10 \%$ level, respectively. Coefficients estimates refer to the benefit equation from the jointly estimated model of unemployment and employment hazards allowing for correlated discrete unobserved heterogeneity. In Ireland the parameter for duration dependence between 6-12 months was not identified so it was restricted to zero. 


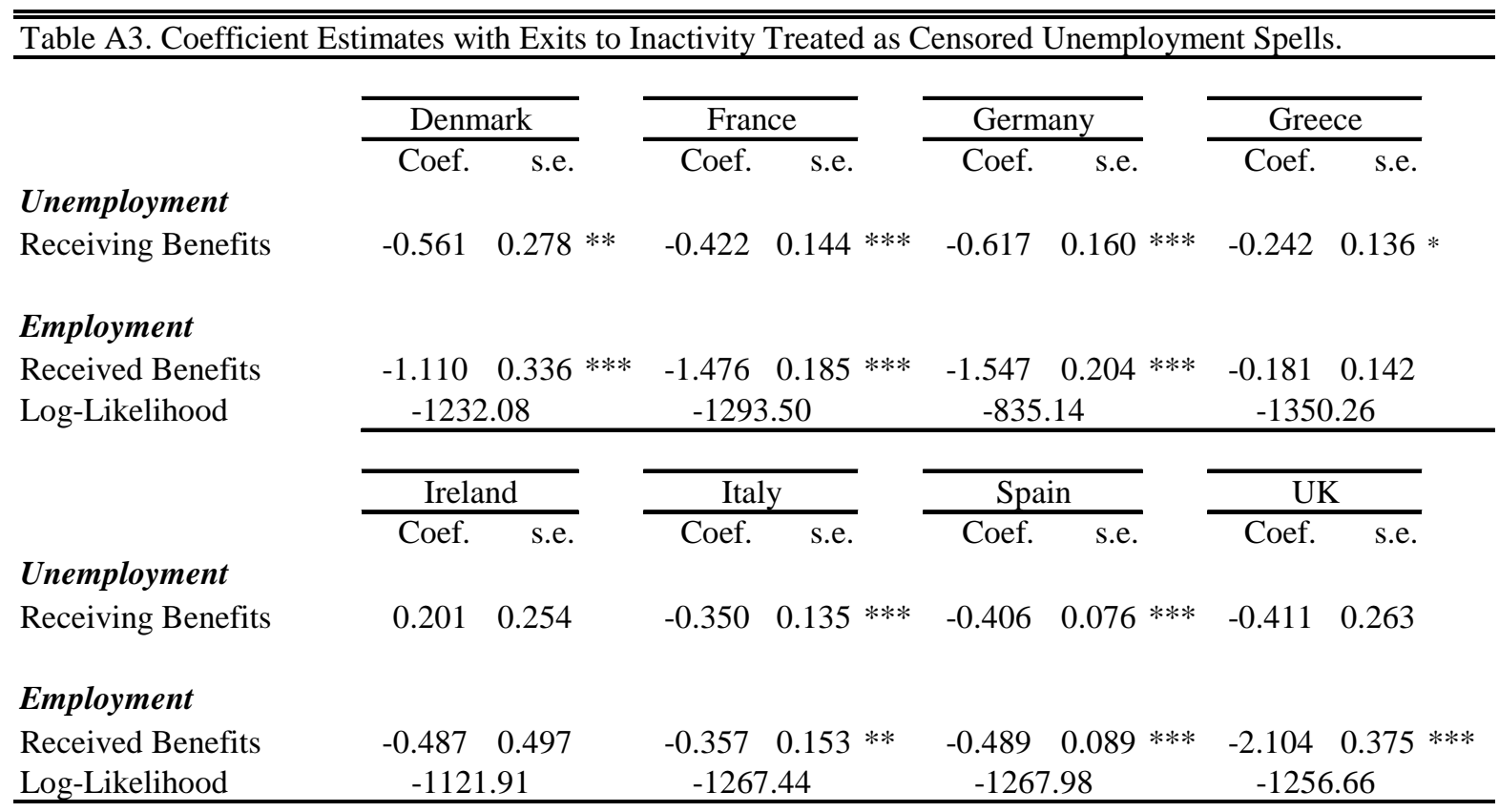

Notes: Exits from unemployment to inactivity are treated as censored unemployment spells. In estimates of Table 4 they are treated as continued unemployment spells. ***,**,and * denote significance at the $1 \%, 5 \%$, and $10 \%$ level, respectively. The unemployment and employment hazard functions are estimated jointly with the benefit equation. Discrete unobserved heterogeneity for each process has two points of support. 